\title{
Single domain antibodies: promising experimental and therapeutic tools in infection and immunity
}

\author{
Janusz Wesolowski $\cdot$ Vanina Alzogaray $\cdot$ Jan Reyelt $\cdot$ Mandy Unger $\cdot$ Karla Juarez $\cdot$ Mariela Urrutia $\cdot$ \\ Ana Cauerhff · Welbeck Danquah · Björn Rissiek · Felix Scheuplein • Nicole Schwarz • Sahil Adriouch • \\ Olivier Boyer • Michel Seman • Alexei Licea • David V. Serreze • Fernando A. Goldbaum • Friedrich Haag • \\ Friedrich Koch-Nolte
}

Received: 15 May 2009 / Published online: 16 June 2009

(C) The Author(s) 2009. This article is published with open access at Springerlink.com

\begin{abstract}
Antibodies are important tools for experimental research and medical applications. Most antibodies are composed of two heavy and two light chains. Both chains contribute to the antigen-binding site which is usually flat or concave. In addition to these conventional antibodies, llamas, other camelids, and sharks also produce antibodies composed only of heavy chains. The antigen-binding site of these unusual heavy chain antibodies (hcAbs) is formed only by a single domain, designated $\mathrm{VHH}$ in camelid hcAbs and VNAR in shark hcAbs. VHH and VNAR are easily produced as recombinant proteins, designated single domain antibodies (sdAbs) or nanobodies. The CDR3 region of these sdAbs possesses the extraordinary capacity to form long fingerlike extensions that can extend into cavities on antigens, e.g., the active site crevice of enzymes. Other advantageous features
\end{abstract}

J. Wesolowski $\cdot$ J. Reyelt $\cdot$ M. Unger $\cdot$ K. Juarez .

W. Danquah · B. Rissiek · F. Scheuplein · N. Schwarz ·

F. Haag · F. Koch-Nolte $(\bowtie)$

Institute of Immunology,

University Medical Center Hamburg-Eppendorf,

Martinistr. 52, 20246 Hamburg, Germany

e-mail: nolte@uke.uni-hamburg.de

V. Alzogaray · M. Urrutia · A. Cauerhff · F. A. Goldbaum Fundación Instituto Leloir,

Consejo Nacional de Investigaciones Científicas y Técnicas,

Patricias Argentinas 435, C1405 Buenos Aires, Argentina

K. Juarez $\cdot$ A. Licea

Centro de Investigación Científica y de Eduación Superior de

Ensenada (CICESE), Ensenada, Mexico

F. Scheuplein · D. V. Serreze

The Jackson Lab, Bar Harbor, ME, USA

S. Adriouch · O. Boyer - M. Seman

Inserm, U905, Institute for Biomedical Research,

Rouen University Hospital, Rouen, France of nanobodies include their small size, high solubility, thermal stability, refolding capacity, and good tissue penetration in vivo. Here we review the results of several recent proofof-principle studies that open the exciting perspective of using sdAbs for modulating immune functions and for targeting toxins and microbes.

Keywords Single domain antibodies - Recombinant antibodies · VHH · Nanobody · Enzyme inhibitors · Virus neutralization

\author{
Abbreviations \\ CDR Complementarity determining region \\ FR Framework region \\ hcAb Heavy chain antibody \\ $\mathrm{sdAb} \quad$ Single domain antibody \\ VHH Variable domain of camelid heavy chain antibody \\ VNAR Variable domain of the shark new antigen receptor
}

\section{Introduction}

The vertebrate immune system generates billions of different antibody molecules. This enormous repertoire contains highly specific binding partners for practically every existing biological and chemical compound. Following immunization, B-cells that express a suitable antibody expand a million-fold by clonal proliferation in lymphatic organs. Well orchestrated mutation and selection mechanisms ensure the preferential expansion of variants that express antibodies with higher affinity to the immunogen. Repeated immunization, thus, generally yields higher quantities and higher affinities of specific antibodies. Hybridoma and genetic engineering technologies can be used to harness and to reformat individual antibodies obtained from immunized 
animals and even to reconstruct recombinant molecules semi-synthetically. Today, monoclonal antibodies and antibody-derived recombinant proteins are essential tools for experimental research and medical applications [1].

The peculiar structure and biochemical features of camelid and shark hcAbs

Most antibodies are composed of two heavy and two light chains (Fig. 1). Both chains contribute to the two identical antigen-binding sites, which are usually flat or concave. In addition to these conventional antibodies, camelids and sharks also produce unusual antibodies composed only of heavy chains (Fig. 1) [2, 3]. These peculiar heavy chain antibodies (hcAbs) lack light chains (and, in the case of camelid antibodies, also the CH1-domain). Therefore, the antigen-binding site of hcAbs is formed only by a single domain that is linked directly via a hinge region to the Fc-domain. The variable domain is designated VHH for camelid hcAbs (Fig. 2) and VNAR for shark hcAbs, and more generally, nanobody or single domain antibody (sdAb) [4].

The CDR3 region of these hcAbs possesses the extraordinary capacity to form long fingerlike extensions that can extend into cavities on antigens, e.g., the active site crevice

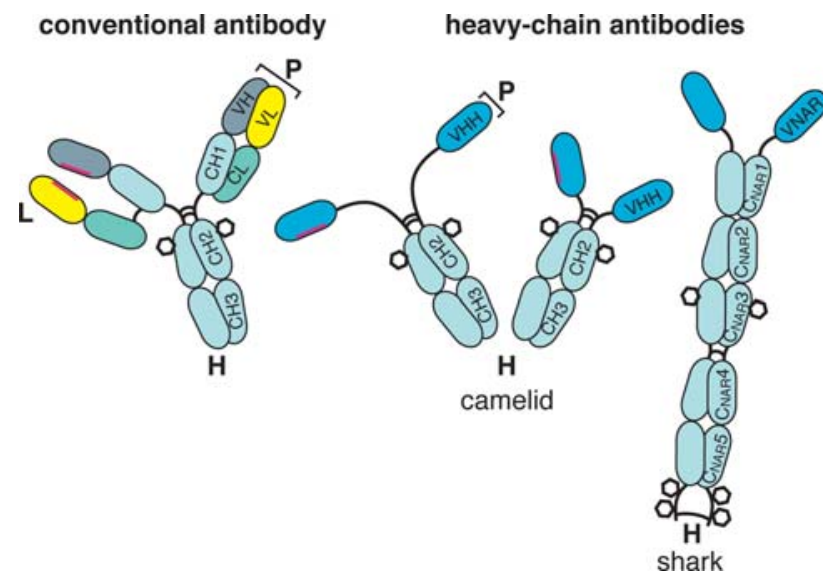

Fig. 1 Distinguishing structural features of camelid and shark hcAbs. Conventional Abs composed of heavy $(\mathrm{H})$ and light $(\mathrm{L})$ chains are found in all vertebrates. Heavy chain antibodies are found in camelids and sharks. Immunoglobulin domains are depicted as ellipsoid domains. Interchain disulfide bonds are indicated by black lines, glycosylation sites as hexagons. The antigen-binding paratope $(\mathrm{P})$ of conventional Abs is formed by the variable domains of heavy and light chains (VH and VL), while the paratope of heavy chain Abs is formed only by the heavy chain variable domain, which is designated VHH in camelid hcAbs and VNAR in shark IgNARs. VH and VL domains in conventional Abs display hydrophobic binding interactions, while the corresponding region in hcAbs is hydrophilic (depicted in pink). Note that in camelid hcAbs the V-domains are directly connected to the hinge region, owing to the lack of the $\mathrm{CH} 1$ domain. Camelid hcAbs come in two variants, distinguished on the basis of the lengths of their hinge region and designated as long- and short-hinge isotypes (as depicted schematically in the diagrams)
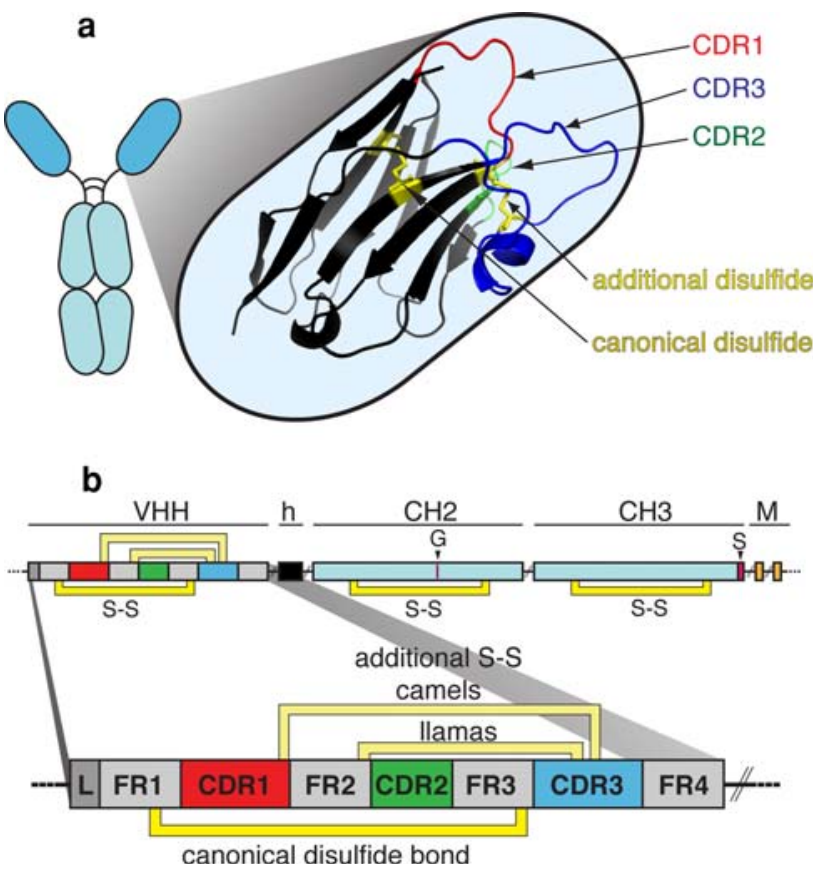

Fig. 2 Schematic diagram of the VHH domain of a camelid heavy chain antibody. a The three complementarity determining regions (CDRs) of the antigen-binding paratope are depicted as colored loops: CDR1 red, CDR2 green, and CDR3 blue. b The canonical disulfide bond connecting framework regions 1 and 3 (FR1 and FR3) in the two $\beta$-sheets of the immunoglobulin domain is indicated in yellow. Many camelid antibodies contain an additional disulfide bond (S-S) connecting the CDR3 with the end of the CDR1 (camels) or the beginning of the CDR2 (llamas). $h$ Hinge, $M$ transmembrane domain of membrane isoform, $G$ glycosylation site, $S$ stop codon of secretory isoform

of enzymes. Figure 3 illustrates this unique antigen-antibody interaction in crystal structures of hen egg lysozyme in complex with an sdAb from shark (a) and camel (b). The CDR3 of these sdAbs can form convex extensions that occupy the cleft for the substrate (Fig. 3c). In contrast, the Fab-fragment derived from a conventional mouse monoclonal antibody binds with a relatively flat interaction face, well outside the active site (Fig. 3d) [5]. Indeed, the immune system of camelids seems to possess an inherent propensity for forming enzyme-blocking hcAbs [6].

The CDR3 of VHHs and VNARs is often much longer than that of conventional VH domains, e.g., 24 and 18 residues in case of the illustrated anti-lysozyme sdAbs versus 7 residues in the mouse VH (Fig. 4) [7, 8]. The extended CDR3 is often, but not always, stabilized by an additional disulfide bond connecting the CDR3 to the adjacent CDR1 loop (common in camel and shark sdAbs) or to the CDR2 loop (common in llama sdAbs) (Figs. 2 and 4). The interface of conventional VH and VL domains is stabilized by hydrophobic interactions, the corresponding residues in llama antibodies are replaced by hydrophilic residues (pink region in Fig. 1 and pink residues in Fig. 4). In shark sdAbs, the CDR2 loop is replaced by two shorter less variable loops (Fig. 4). 


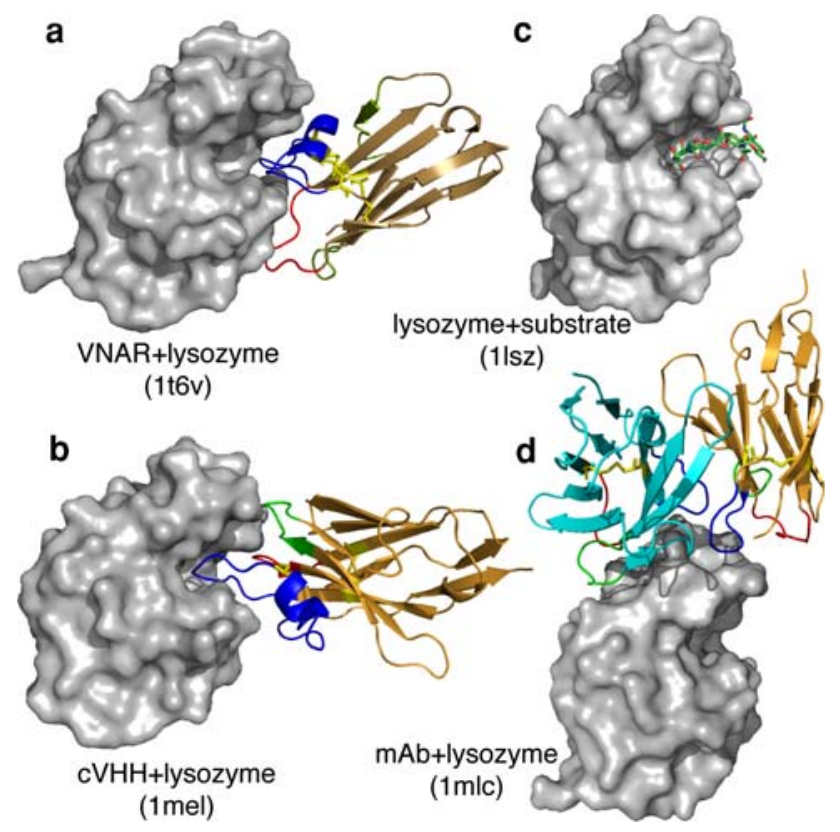

Fig. 3 3D-structures of enzyme-inhibiting sdAbs derived from camel and shark hcAbs. Images were generated with the PyMOL program [123]. The three CDR loops are color-coded as in Fig. 2: CDR1 red, CDR2 green, CDR3 blue, and disulfide bonds are depicted in yellow. a Chicken lysozyme in complex with an inhibitory shark sdAb VNAR (pdb code 1t6v). The VNAR contacts the enzyme only with its CDR1 and CDR3 regions, the latter extends into and blocks the active site crevice [124]. b Chicken lysozyme in complex with an inhibitory camel $\mathrm{sdAb}$ (pdb code 1mel). The CDR3 extends into and fills out the active site crevice of the enzyme [5]. c Chicken lysozyme in complex with its substrate (pdb code 1lsz) [125]. d Chicken lysozyme in complex with the VL and VH domains of a conventional mouse mAb (pdb code $1 \mathrm{mlc})$. The flat interaction surface with the conventional antibody lies outside of the active site crevice [126]

Molecular cloning and reformatting of camelid and shark sdAbs

sdAbs are usually generated by PCR cloning of the V-domain repertoire from blood, lymph node, or spleen cDNA obtained from immunized animals into a phage display vector, such as pHEN2 (Fig. 5). Antigen-specific sdAbs are commonly selected by panning phage libraries on immobilized antigen, e.g., antigen coated onto the plastic surface of a test tube, biotinylated antigens immobilized on Streptavidin beads, or membrane proteins expressed on the surface of cells. Several labs have also constructed semi-synthetic libraries by cassette-mutagenesis of the CDR regions. The latter offers the advantage of selecting antibodies against toxic or difficult to express antigens. However, sdAbs derived from such non-immune libraries often show lower affinities for their antigen than sdAbs derived from animals that have received several immunizations [8-10]. The high affinity of sdAbs from immune libraries is attributed to the natural selection of variant sdAbs during clonal expansion of B-cells in the lymphoid organs of the immunized animals. The affinity of sdAbs from non-immune libraries can often be improved by mimicking this strategy in vitro, i.e., by site directed mutagenesis of the CDR regions and further rounds of panning on immobilized antigen under conditions of increased stringency (higher temperature, high or low salt concentration, high or low $\mathrm{pH}$, and low antigen concentrations).

sdAbs derived from camelid and shark hcAbs are readily expressed in and purified from the E. coli periplasm at much higher expression levels than the corresponding domains of conventional antibodies (Fig. 6). sdAbs generally display high solubility and stability and can also be readily produced in yeast, plant, and mammalian cells [8].

Recombinantly expressed sdAbs display several advantages as compared to conventional antibodies and the single chain variable fragments ( $\mathrm{scFv})$ derived from the V-domains of conventional antibodies. Their high thermal stability, high refolding capacity, and good tissue penetration in vivo $[3,11,12]$ make nanobodies ideally suited for various biotechnological and therapeutic applications. Moreover, sdAbs can be readily cloned into various formats by fusion to other proteins or peptides, thereby tailoring their utility for certain diagnostic and/or therapeutic applications (Fig. 7) [13]. For example, fusion to a fluorescent protein yields a fluorescent probe (also designated chromobody or

\begin{tabular}{|c|c|c|c|c|}
\hline & & CDR1 & CDR2 & FR3 \\
\hline mAbVH & $(1 \mathrm{mlc})$ & \multicolumn{3}{|c|}{ 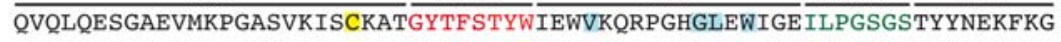 } \\
\hline $\mathrm{CVHH}$ & (1mel) & \multicolumn{3}{|c|}{ DVQLQASGGGSVQAGGSLRLSCAASGYTIGPYCMGWERQAPGKEREGVAAINMGGGITYYADSVKG } \\
\hline IVHH & & \multicolumn{3}{|c|}{ QVQLQESGGGLVQPGGALRLSCAASGLTLADTATGWERQAPGKEREWVACISRRKAGTFYADSLKD } \\
\hline \multirow[t]{3}{*}{ VNAR } & & \multicolumn{3}{|c|}{ RVD-QTPRSVTKETGESLTINCVLRDASYALGSTCWYRKKSGE----------GNEESISKG---G } \\
\hline & & \multicolumn{3}{|c|}{ HV2 } \\
\hline & & FR3 & CDR3 & FR4 \\
\hline nAbVH & $\mathrm{mlc}$ ) & \multicolumn{3}{|c|}{$\overline{\text { KATFTADTSSNTAYMQLSSLTSEDSAVYYCARGDG----------------NYGYWGQGTTLTVSS }}$} \\
\hline $\mathrm{CVHH}$ & (1mel) & \multicolumn{3}{|c|}{ RFTISQDNAKNTVYLLMNSLEPEDTAIYYCAADSTIYASYYECGHGLSTGGYGYDSWGQGTQVTVSS } \\
\hline IVHH & $s+16 a$ & \multicolumn{3}{|c|}{ RFTISRDDSVNTVYLQIISLKPDDTANYVCVQIPFCNEF--------MRGDLDRAILGQGTQVTVAS } \\
\hline VNAR & $(1 \mathrm{t} 6 \mathrm{v})$ & \multicolumn{3}{|c|}{ RYVETVNSGSKSFSLRINDLTVEDGGTYRCGLGVAGGYCD-------YALCSSRYAECGDGTAVTVN- } \\
\hline
\end{tabular}

Fig. 4 Amino-acid sequence alignment of heavy chain variable domains of conventional (VH), camelid (VHH), and shark (VNAR) antibodies. Amino acids are color-coded as in previous figures: CDR1 red, CDR2 green, CDR3 blue, hydrophilic motif in FR2 pink, and cysteine residues yellow. The sequences are derived from the anti-lysozyme $\mathrm{VH}$ (mAbVH), VHH (cAbLys3), and VNAR domains shown in Fig. 3a, b, and $\mathrm{d}$. VHH s+16a is an enzyme-blocking sdAb derived from a llama immunized with the murine T-cell ecto-enzyme ART2.2 [29] 


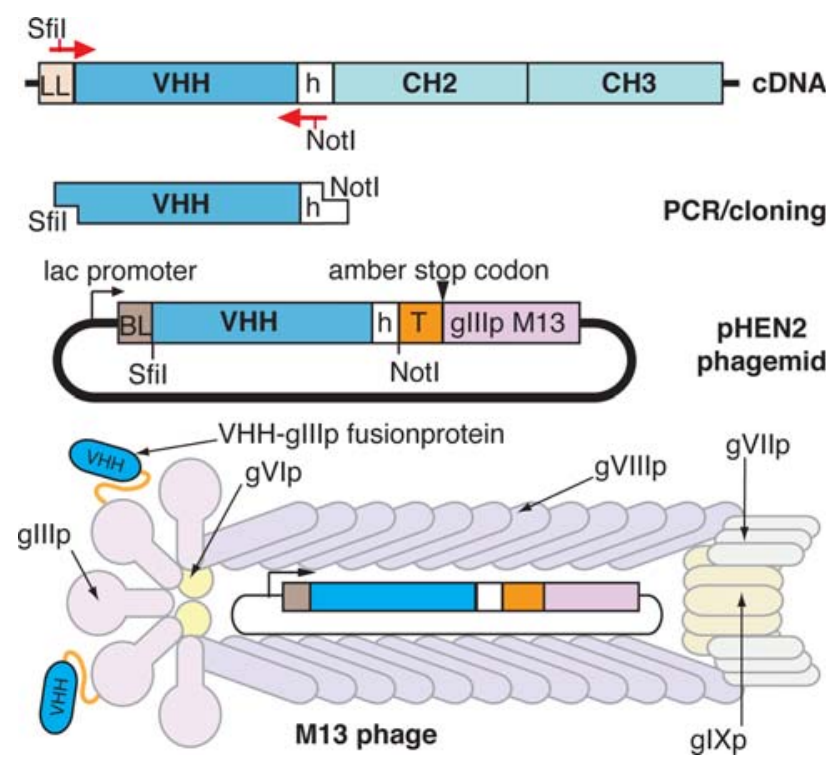

Fig. 5 Schematic diagram of the M13 phage display vector used for cloning libraries of the VHH and VNAR repertoires of immunized camelids and sharks. The open reading frame of the V-domains from hcAbs are PCR amplified from cDNA generated from lymphocytes purified from peripheral blood, lymph node, or spleen cDNA of an immunized animal, typically obtained 4-14 days after the final boost. The purified PCR amplification products are cloned into the phagemid vector downstream of an inducible bacterial promoter (arrow), in-frame behind a periplasm signal sequence $(B L=$ bacterial leader peptide) and upstream of one or two epitope tags (T), an amber stop codon followed by the coding sequence of the M13 phage head capsid protein gIIIp. The phagemids are transfected into an E. coli strain that can read through the amber stop codon. Following infection with a helper phage, libraries of recombinant phage particles are harvested from bacterial culture supernatants and phages displaying sdAbs of interest are selected by panning on immobilized antigen. Bound phages are subjected to one or more additional rounds of selection. Phagemids are recuperated from single colonies of infected E. coli and the cDNA insert subjected to sequencing

fluobody) suitable for tracking the target antigen in cells $[14,15]$. Tandem cloning of two identical sdAbs connected by a linker peptide yields a bivalent reagent with higher avidity for the antigen [13]. Tandem cloning to an $\mathrm{sdAb}$ with a distinct specificity, e.g., for serum albumin, can help target the reagent to a particular compartment and/or help to increase the in vivo half life of the reagent [16]. A bivalent $\mathrm{hcAb}$ can be reconstituted by genetic fusion to the Fc-domain of any conventional antibody, e.g., mouse or human $\operatorname{IgG1}$. Fusion to a cell surface protein, e.g., of lactobacillus, a commensal gut bacterium, yields a reagent designated lactobody with a massively increased binding surface for the antigen of interest, e.g., rotavirus, the etiological agent of severe diarrhea in children [17]. Owing to their high stability and excellent folding capacity under different environmental conditions, sdAbs have also been targeted successfully to the cytosol by removing the leader peptide [18] and to intracellular vesicles, such as chloro-

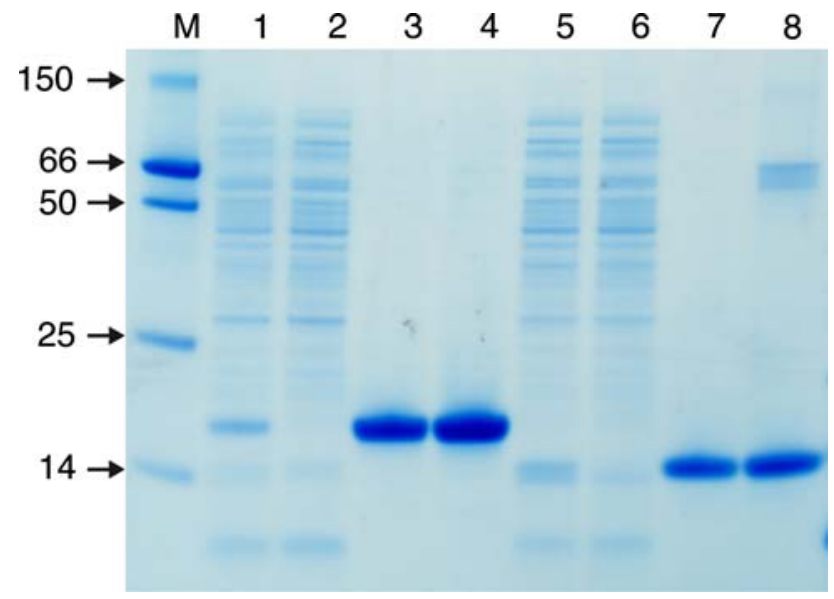

Fig. 6 Expression and purification of sdAbs. Single domain antibodies carrying $\mathrm{C}$-terminal epitope tags are readily generated following transfection of the phagemids into an E. coli strain that recognizes the amber stop codon. sdAbs can be purified from periplasmic lysates by affinity chromatography, e.g., on immobilized nickel ions, as illustrated in this Coomassie stain of a llama VHH (lanes 3 and 4) and of a shark VNAR (lanes 7 and 8) directed against the lymphocyte ectoenzyme CD38. Periplasmic lysates obtained from the cell pellets of $100 \mathrm{ml}$ E. coli cultures were subjected to affinity chromatography on $1 \mathrm{ml} \mathrm{Ni-NTA}$ columns. Aliquots of protein suspensions obtained during purification were size fractionated by SDS-PAGE and stained with Coomassie. Lanes 1 and 5: total proteins in periplasmic lysates as loaded onto the column, lanes 2 and 6: column flow through, lanes 3-4 and 7-8 proteins eluted from the Ni-NTA column by imidazole. The protein yield from the $100 \mathrm{ml} \mathrm{E}$. coli culture was $0.5-1 \mathrm{mg}$ of sdAb. $\mathrm{M}=$ molecular weight markers, size indicated in kilodalton $(\mathrm{kD})$

plasts [19] or the endoplasmic reticulum [20] by genetic fusion to suitable targeting sequences.

\section{Single domain antibodies in immunity}

The remarkable success of conventional TNF- $\alpha$ neutralizing antibodies in the therapy of rheumatoid arthritis and other inflammatory diseases [21] have fueled the quest for other antibody-based therapeutic tools. Many new antibody-based reagents have hence been licensed for the treatment of auto-immune diseases and allergies, as well as for the immune therapy of cancers [22]. For example, B-cell depletion mediated by an antibody against CD20 (Rituximab/Rituxan) shows beneficial effects in rheumatoid arthritis, systemic lupus erythematosus, and other autoimmune diseases, an antibody against IgE has been approved for the therapy of severe asthma (Omalizumab/Xolair), and antibodies against the epidermal growth factor receptors ErbB-1 and ErbB-2 (Cetuximab/Erbitux and Trastuzumab/ Herceptin) for the therapy of colorectal and breast cancers.

The very high cost of conventional antibodies is already becoming a major burden for the health care budgets in many countries [23]. Roche, for example, has invested several hundred million Euros for a new production facility 


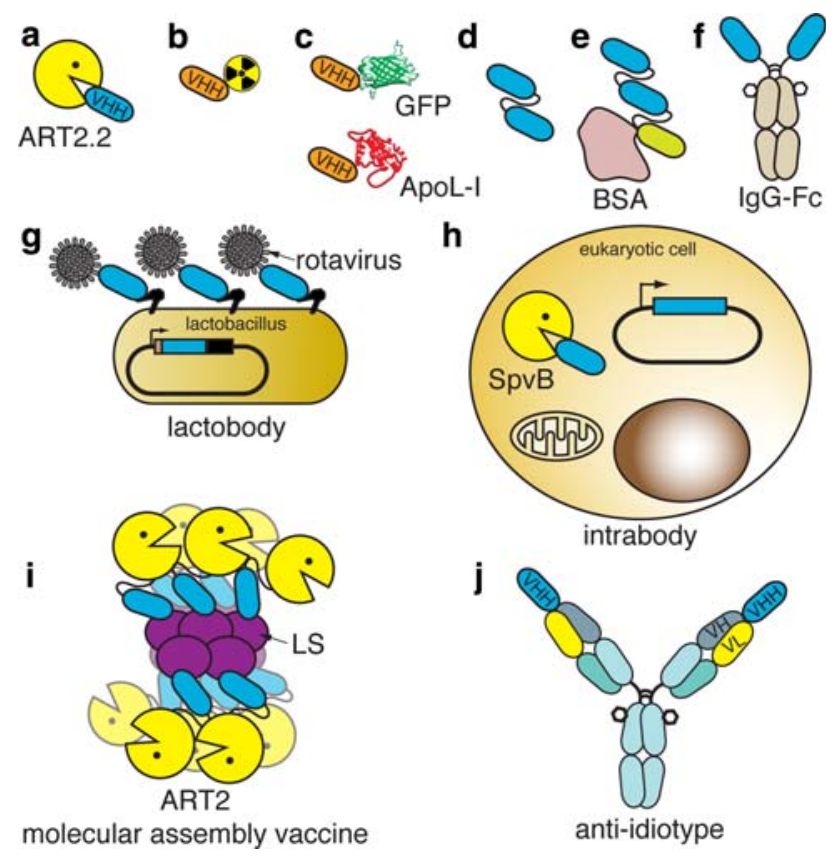

Fig. 7 Schematic diagram of various formats of recombinant sdAbs. a Monovalent sdAbs can be obtained directly from E. coli transfected with phagemids selected as illustrated in Fig. 6. These sdAbs can be used to block enzymes, such as T-cell ecto-ADPribosyltransferase ART2.2, here symbolized by the Pacman [29]. b Monovalent sdAbs can be conjugated chemically to radioisotopes, fluorochromes, biotin, magnetic beads, affinity matrices, etc. Radiolabeled sdAbs can be used for in vivo imaging of tumors [43]. c Fusion of sdAbs to other proteins, such as green fluorescent protein (GFP) $[127,128]$ or the trypanolytic serum protein apolipoprotein A [101] is accomplished by recloning of the PCR-amplified insert into appropriate expression vectors. d Bivalent sdAbs are generated by tandem cloning of two V-domains separated by a flexible linker peptide of 12-20 amino acids [13]. e The same strategy can be applied to fuse two distinct sdAbs, e.g., one encoding an albumin-specific sdAb, the other encoding a cytokine-specific $s d A b$ [16]. Inclusion of an albumin-specific sdAb results in a dramatically increased in vivo half-life upon binding to albumin. $\mathbf{f}$ A bivalent hcAb format can be regenerated by fusion of the $\mathrm{V}$-domain to an IgG-Fc-domain [77]. The increased avidity is useful for diagnostic purposes. Moreover, the hcAb format has a dramatically increased serum half-life, which can be of great value for certain therapeutic applications. g Fusion of an sdAb to a bacterial outer membrane protein yields recombinant bacteria exposing hundreds of copies of the sdAb on the cell surface, as in the illustrated example of a rotavirus-specific VHH fused to an outer membrane protease of a commensal gut bacterium [17]. h Intracellular sdAbs are generated by recloning the VHH (without the leader peptide) into a eukaryotic expression vector. Transfection of cells with an SpvBspecific sdAb protects cells from the cytotoxic action of the Salmonella SpvB ADP-ribosyltransferase (here indicated by the Pacman). Targeting to organelles can be achieved by fusion of appropriate targeting sequences (not shown) [19, 20]. i sdAbs directed against multimeric lumazine synthase (LS) can be used for the construction of highly immunogenic molecular assembly vaccines. This could be used to enhance the antibody response against an ADP-ribosyltransferase (here illustrated as a Pacman) fused to an LS-specific sdAb. $\mathbf{j}$ sdAbs directed against the idiotype of a conventional antibody can be used for molecular mimicry of the target antigen [64]
(Biologics IV in Penzberg) for the production of one antibody (Trastuzumab) and a similar facility (Building 95 in Basel) for the production of Bevacizumab (anti-VEGF). Owing to their smaller size and ease of production, sdAbs present an interesting alternative to conventional antibodies for immune therapy. Potential targets include cell surface proteins, cytokines, other secreted proteins, and even intracellular proteins (Table 1).

\section{Targeting leukocyte ecto-enzymes}

Leukocytes express numerous ecto-enzymes that have their active sites exposed to the extracellular environment. These enzymes play important roles in cell trafficking, inflammation, and apoptosis [24, 25]. For example, NAD-dependent ADP-ribosyltransferases (ARTs, also named CD296) regulate the function of other cell surface proteins by posttranslational modification [26, 27]. Other nucleotidemetabolizing ecto-enzymes (CD38, CD39, CD73, CD157, and CD203) control the half-life of purinoreceptor-ligands and/or generate signaling molecules, such as cyclic ADPribose, adenosine, and lysophosphatidic acid [28]. Peptidases (CD10, CD13, CD26, CD156, and CD249) control the shedding and processing of cytokines and cell adhesion molecules. Given the important regulatory functions of these enzymes, specific inhibitors of their activities might be useful as tools to modulate immune functions [25].

Small molecule inhibitors and antibodies offer two possible strategies for inhibiting leukocyte ecto-enzymes [1, 25]. While small chemical antagonists often lack specificity, antibodies have the capacity to discriminate between closely related enzymes. As leukocyte cell surface ectoenzymes are accessible to antibodies, the remarkable preference of hcAbs for binding into the active sites of enzymes offers the possibility to raise selective enzyme-blocking sdAb-reagents $[5,6]$. The crystal structures of several leukocyte ecto-enzymes have been elucidated, and in many cases they display a deep active site crevice that may be suitable for targeting by sdAbs (Fig. 8a, b).

In a recent proof-of-principle study, we have generated sdAbs against the toxin-related murine T-cell ecto-ADPribosyltransferase ART2.2 (Table 1; Fig. 7a) [29]. This cell surface enzyme plays an important regulatory role in inflammatory settings, where it senses NAD released from damaged cells [30-32]. ART2.2 mediates NAD-induced cell death of naive T-cells by ADP-ribosylating the cytolytic P2X7 receptor [33, 34]. Three out of four distinct ART2.2-specific VHHs isolated from an immune llama phage display library were found to block the enzymatic activity of ART2.2 [29]. Following intravenous injection, a VHH (s+16a) was able to completely block ART2.2 enzymatic activity and NAD-induced cytotoxicity on the surface 
Table 1 Applications of sdAbs in immunity

\begin{tabular}{|c|c|c|c|}
\hline Target & Application & Source of $s d A b$ & Reference \\
\hline \multicolumn{4}{|l|}{ Membrane proteins } \\
\hline ART2.2 & $\begin{array}{l}\text { Blocking T-cell ecto-enzyme, } \\
\text { treatment of auto-immune disease }\end{array}$ & Immune llama & [29] \\
\hline CD16 & Activation of NK cells & Immune llama & [36] \\
\hline$\alpha 3 \beta 1$ Integrin VLA-3 & Block leukocyte-matrix adhesion & Immune llama & {$[37]$} \\
\hline$\alpha 2,3$ Sialoglyco-protein & Crossing the blood brain barrier & Non-immune llama & {$[38,39]$} \\
\hline EGFR & In vivo imaging, cancer immunotherapy & Immune camel, immune llama & {$[41-44,110,111]$} \\
\hline CEA & Cancer immunotherapy & Immune llama & {$[40]$} \\
\hline MUC 1 & Tumor targeting & Immune camel and llama & {$[45,112]$} \\
\hline CD105 (endoglin) & Tumor targeting & Immune camel & {$[46]$} \\
\hline \multicolumn{4}{|l|}{ Secretory proteins } \\
\hline $\mathrm{TNF} \alpha$ & Cytokine neutralization & Immune llama and alpaca & {$[16,48,113]$} \\
\hline PSA & Cancer diagnosis & Immune dromedary & {$[114,115]$} \\
\hline von Willebrand factor & Blocking blood clotting & Immune llama & {$[50]$} \\
\hline Amyloid $\mathrm{A} \beta$ peptide & Amyloid aggregation & Immune dromedary and alpaca & {$[53,54]$} \\
\hline Lysozyme & Amyloidosis & Immune dromedary & {$[12,52,116]$} \\
\hline $\operatorname{IgG}$ & Depletion of auto-Abs & Immune llama & {$[55]$} \\
\hline Serum albumin & Bispecific sdAbs, increase serum half-life & Immune llama & {$[16,44]$} \\
\hline \multicolumn{4}{|l|}{ Intracellular proteins } \\
\hline Bax & Inhibiting apoptosis & Non-immune llama & {$[18]$} \\
\hline $\mathrm{HIF}-1 \alpha$ & Hypoxia response & Non-immune llama & {$[58,59]$} \\
\hline PABPN1 & Aggregation disorders & Immune and non-immune llama & {$[60,117,118]$} \\
\hline \multicolumn{4}{|l|}{ Vaccine enhancement } \\
\hline Lumazine synthase & Molecular assembly vaccines & Immune llama & $\begin{array}{l}\text { Urrutia, } \\
\text { Danquah et al. } \\
\text { (unpublished) }\end{array}$ \\
\hline \multicolumn{4}{|l|}{ Molecular mimicry } \\
\hline Immunoglobulin idiotype & Molecular mimicry & Immune llama, non-immune shark & {$[64,65]$} \\
\hline
\end{tabular}

of T-cells in peripheral lymphatic organs in vivo. This blockade was effective from within $10 \mathrm{~min}$ for at least $6 \mathrm{~h}$ after injection. Subsequently, we constructed a chimeric single domain antibody composed of VHH s+16a fused to the Fc-domain of mouse IgG1 (Fig. 7f). Following i.v. injection, these reconstituted chimeric hcAbs achieved complete blockade of ART2.2 on lymph node cells within $2 \mathrm{~h}$ after injection. This somewhat slower inhibition than sdAbs likely reflects the slower tissue penetration capacity of the larger Fc-fusion protein. The blockade of ART2.2 by $\mathrm{s}+16 \mathrm{a}-\mathrm{Fc}$ was effective for $>7$ days, reflecting the higher in vivo half-life due to slower elimination via the kidney and a high affinity interaction with the anti-catabolic FcRn molecule [35]. These antibodies provide unique tools to specifically block the activity of a single member of the ART-family of ecto-ADP-ribosyltransferases. Our ongoing studies address the potential therapeutic utility of these antibodies in autoimmune and other inflammatory diseases.

By analogy to ART2.2, other leukocyte ecto-enzymes with deep active site crevices, such as CD38 (Fig. 8b),
CD39, CD203, and CD151 are potential therapeutic targets [25]. With the goal of generating and cloning enzymeblocking sdAbs against these enzymes, we have initiated immunizations of llamas and sharks with some of these enzymes.

Targeting other cell surface proteins with sdAbs

Leukocytes and other cells express numerous other functionally important membrane proteins that are not enzymes, including receptors, ion channels and transporters. Recently, nanobodies directed against the CD16 Fc-receptor on natural killer (NK) cells were developed from an immunized llama [36]. Once multimerized via biotin/Streptavidin interactions, these sdAbs were capable of activating NK cells, which makes them good candidates to be used in bi-specific formats for recruiting NK cells to target and destroy tumor cells. From a llama immunized with the human A431 squamous cancer cell line, an sdAb specific for the $\alpha 3 \beta 1$ integrin (VLA-3) was isolated that could 


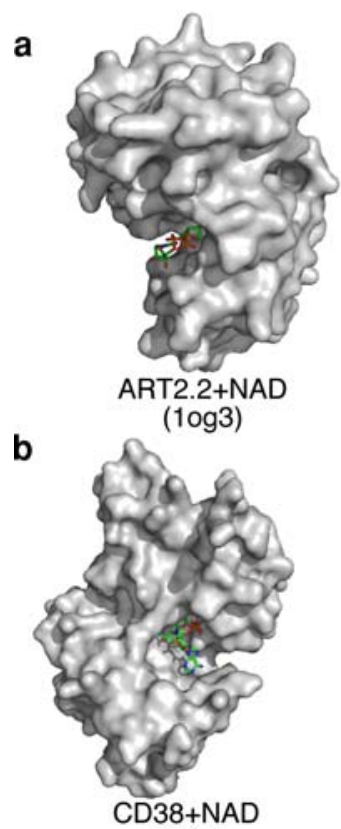

(2i65)

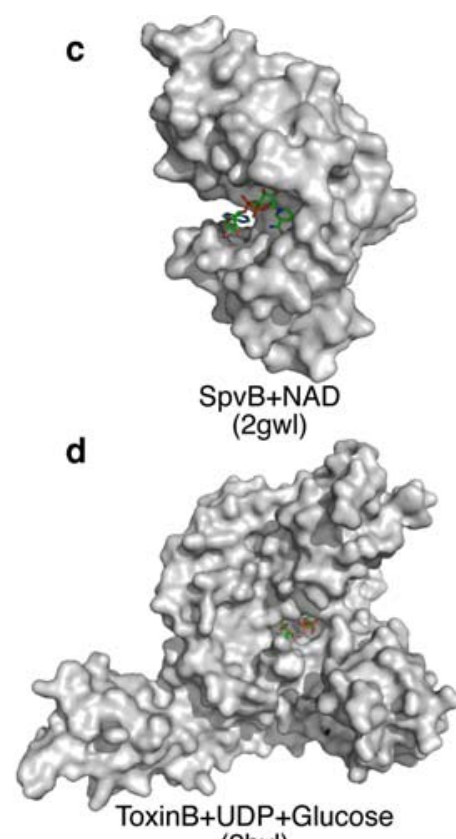

(2bvl)
Fig. 8 3D-structures of leukocyte ecto-enzymes and toxin enzymes with active site crevices targeted by sdAbs. a Murine T-cell ecto-ADPribosyltransferase ART2.2 with substrate NAD (pdb code $1 \log 3$ ). b Human lymphocyte ecto-NAD-glycohydrolase CD38 with substrate NAD (pdb code 2i65). c Salmonella enterica virulence protein SpvB, an actin ADP-ribosyltransferase, with NAD (pdb code 2gwl). d Clostridium difficile toxin $\mathrm{B}$, a rho glucosyltransferase (pdb code $2 \mathrm{bvl}$ ). Images were generated with the PyMOL program [123]. We have already generated enzyme-blocking sdAbs against ART2.2 and SpvB from immunized llamas. Current work aims at generating similar antibodies against CD38 and Toxin B from immunized llamas and sharks

inhibit the binding of K562 erythroleukemia cells to the extracellular matrix [37].

In search of an agent that could be used to surmount the blood brain barrier, a llama was immunized with brain vascular endothelial cells [38]. One of the selected sdAbs, directed against $\alpha 2-3$ sialoglycoprotein, was found to induce transcytosis of the sdAb through and release on the basolateral side of endothelial cells [39]. In vivo studies showed that this sdAb was efficiently transported across the blood brain barrier and could even be used to carry genetically fused cargo into the brain, including the entire M13 phage particle [38].

Several sdAbs have been raised against receptors overexpressed in tumors and/or tumor neovasculature with the goal of generating tools for improving immune therapy of tumors. Carcinoembryonic antigen (CEA, also named CD66e) is highly expressed on cancer cells of epithelial origin, but not at all or only at low levels by adult cells. A CEA-specific sdAb derived from an immunized dromedary (cAb-CEA5) was fused to a $\beta$-lactamase, an enzyme that can convert non-toxic prodrugs into potent cytotoxic agents
[40]. The fusion protein was found to localize preferentially in tumors and to be cleared rapidly from the circulation via the kidney. The combined treatment with sdAb-lactamase fusion protein and an anticancer prodrug induced regressions and cures of established tumor xenografts [40]. Several groups have raised sdAbs against the epidermal growth factor receptor (EGFR) [41-44]. Both, monovalent (17 kD) and bivalent $(35 \mathrm{kD})$ formats showed rapid tissue penetration as well as rapid clearance via the kidney. Conjugation of monovalent sdAb to technetium-99 m (Fig. 7b), a short lived gamma ray emitting isotope widely used in nuclear medicine, permitted in vivo discrimination of EGFR expressing tumors [43]. Tandem fusion of two anti-EGFR VHHs with a VHH specific for serum albumin (Fig. 7e) yielded a $50 \mathrm{kD}$ single-chain reagent that also exhibited excellent tissue penetration [44] with faster and deeper tumor penetration than cetuximab, a conventional chimeric monoclonal antibody currently used in the therapy of metastatic colorectal cancer and squamous cell carcinoma of the head and neck. Fusion to the albumin-specific sdAb resulted in markedly enhanced serum half-life [44].

sdAbs recognizing mucin MUC1, an epithelial cell surface protein over-expressed during lactation and in breast cancer, and endoglin (CD105), an endothelial cell surface protein associated with tumor neovascularization, were isolated from immunized dromedaries and camels [45, 46], yielding potential tumor targeting agents for cancer therapy.

Targeting cytokines with sdAbs

In recent years, cytokine-neutralizing conventional antibodies have revolutionized the therapy of rheumatoid arthritis, psoriasis, and other chronic inflammatory diseases [21, 47]. The great success of these antibodies has prompted the quest for developing smaller, cytokine-neutralizing sdAbs from camelids and sharks. TNF- $\alpha$ blocking sdAbs have been isolated from a llama immunized with human and mouse TNF- $\alpha$ [16] as well as from alpacas immunized with ovine TNF- $\alpha$ [48]. Tandem fusion of two human TNF- $\alpha$ specific VHHs (Fig. 7d) yielded bivalent sdAbs with increased avidity and a more than 100-fold increased TNF- $\alpha$ neutralizing activity [16]. These bivalent sdAbs were markedly more effective at neutralizing TNF- $\alpha$ than the conventional TNF- $\alpha$ blocking antibodies infliximab and adalimumab. Fusion to a third VHH specific for serum albumin (Fig. 7e) yielded potent TNF- $\alpha$ neutralizing sdAbs with enhanced serum half-life and enhanced targeting to inflamed joints in a mouse model of collagen induced arthritis. Daily treatments initiated at the onset of clinical symptoms significantly reduced clinical severity. These sdAbs are currently being developed for clinical trials [49]. 
Targeting other soluble proteins with sdAbs

Like cytokines, other secreted molecules that are functionally important are accessible to sdAbs. Nanobodies have been developed against components of the blood clotting cascade and against aggregation-prone proteins implicated in amyloid diseases. An sdAb (AU/VWFa11) derived from an immunized llama specifically recognizes the activated form of von Willebrand factor (vWF), a key component of the blood-clotting cascade that mediates the tethering of platelets to the vascular endothelial wall [50]. This sdAb proved useful for determining the levels of activated vWF in serum samples, although it did not block the interaction between vWF and its cognate integrin GpIb $\alpha$ on the endothelial cells. Another vWF-specific sdAb has recently completed phase $\mathrm{Ib}$ clinical trial as an anti-thrombotic reagent, showing dose dependent essentially complete inhibition of vWF for a duration of 4 to $18 \mathrm{~h}$ for single dose applications and up to $24 \mathrm{~h}$ in multi-dose applications (http:// www.Ablynx.com).

Amyloidosis is a group of diseases caused by unusual aggregation of proteins into amyloid fibrils. The extracellular accumulation of amyloid $\mathrm{A} \beta$ peptide in insoluble aggregates is associated with Alzheimer's disease. The use of specific antibodies for inhibiting fibril formation seems a promising therapeutic strategy [51]. An sdAb (cAb-HuL6) derived from a dromedary immunized with wild type human lysozyme [52] inhibited the in vitro aggregation of the amyloidogenic $\mathrm{D} 67 \mathrm{H}$ variant of lysozyme [12]. An A $\beta$-specific VHH (V31-1) isolated from an $\mathrm{A} \beta$-peptide-immunized alpaca, was shown to preferentially bind to the oligomeric form of $\mathrm{A} \beta$. Moreover, this VHH inhibited fibril formation and protected neurons in vitro from $\mathrm{A} \beta$-induced neurotoxicity [53]. A conformation sensitive VHH (B10), selected from a fully synthetic camelid library recognizes an epitope common to different amyloid fibrils derived from $\mathrm{A} \beta$ peptide, Ig light chains, and serum amyloid protein [54].

sdAbs directed against human serum albumin and $\mathrm{IgG}$, isolated from immune llama libraries, have been shown to be useful for the bulk depletion of these proteins from serum. Removal of immunoglobulins can have therapeutic benefit, for patients with high titers of circulating autoantibodies, e.g., Goodpasture syndrome and systemic lupus erythematosus (SLE) [55]. sdAbbased affinity-columns showed superior performance to conventional protein A columns. sdAbs directed against human and mouse serum albumin were shown to increase the in vivo half-life of bispecific sdAb reagents (Fig. 7e).
Targeting intracellular proteins with sdAbs-intrabodies, translocation peptides, and CDR3 peptide mimetics

The cell membrane is impermeable to proteins and, therefore, intracellular antigens are inaccessible to secreted antibodies. Two experimental strategies have been pursued to allow access of sdAbs to intracellular targets: the fusion of sdAbs to peptides mediating translocation across the cell membrane and transfection of cells with cDNA constructs encoding intracellular sdAbs. Several natural proteins are equipped with specialized domains that mediate membrane translocation. In some cases, transplantation of such a translocation domain (td) onto another protein has yielded constructs capable of membrane translocation, albeit with highly variable efficiencies. Such td-fusion proteins were constructed of a conventional single-chain variable fragment $(\mathrm{scFv})$ against the $\mathrm{Bcl}-2$ anti-apoptotic protein [56] and against the c-myc oncogene [57]. Very high concentrations of these scFv-td fusion proteins had to be added to cells to yield detectable pro-apoptotic effects on Bcl-2 or anti-proliferative effects on c-myc. The requirements for protein translocation across the cell membrane are poorly understood, but it is likely to involve retrograde transport to an internal compartment, unfolding of the protein, translocation through a channel, and refolding in the cytosol. It is conceivable that the presence of intrachain disulfide bonds could hamper the unfolding and translocation steps and that replacement of the canonical cysteine pair in the Ig-domain (Fig. 2) might improve translocation efficiency of sdAbs.

The alternative strategy involves transfection of cells and co-expression of the sdAb in the same cellular compartment as the target protein. sdAbs appear particularly suited for this strategy as they can readily fold in different environments, including the cytosol, nucleus, and chloroplasts. Cell death induced by oxidative stress is involved in pathologies of post-mitotic tissues, such as brain and heart. Bax, a $24 \mathrm{kD}$ protein of the Bcl-2 family, is involved in the early phase of apoptosis and has been implicated in neuronal death in ischemia. Specific Bax inhibitors hold promise as therapeutic tools for neurodegenerative disorders. Bax-specific sdAbs isolated from a naïve llama library were shown to inhibit Bax induced permeabilization of isolated mitochondria. Cell lines stably transfected with expression constructs for cytosolic anti-Bax sdAbs were found to be resistant to oxidative stress and showed significantly reduced $\mathrm{H}_{2} \mathrm{O}_{2}$-induced cytotoxicity [18].

Hypoxia triggers a transcriptional response, largely mediated by hypoxia-inducible factor- 1 alpha (HIF-1 $\alpha$ ) which regulates the metabolic adaptation to reduced oxygen levels. This metabolic adaptation allows tumor cells to thrive 
despite a low-blood supply in growing tumors. HIF- $1 \alpha$-specific sdAbs selected from a non-immune llama phage display library were shown to be useful for diagnostic purposes and for immunoprecipitation of HIF- $1 \alpha$. These sdAbs are currently being studied for possible functional modulation of HIF- $1 \alpha$ function when expressed as intrabodies [58, 59].

Overexpression and/or trinucleotide repeat expansion in the coding region of poly-A-binding protein 1 (PABN1) can result in fibril-like aggregation of PABN1 in the nuclei of skeletal muscle cells, resulting in oculopharyngeal muscular dystrophy (OPMD). A PABN1-specific sdAb was selected from a non-immune llama library and fused in-frame to a nuclear localization signal and green fluorescent protein [60]. Transfection of this construct into HeLa cells confirmed successful expression and tagging to the nucleus. The construct was found to completely block aggregation of co-expressed PABN1 and was even capable of clearing already existing aggregates when transfected after PABN1. In a Drosophila model of OPMD, expression of a PABN1specific intrabody strongly suppressed muscle degeneration, leading to nearly complete rescue.

These findings underscore the potential of using sdAbs for targeting intracellular as well as extracellular proteins. A transfection-based expression strategy seems, in principle, applicable for transgenic animals and plants, as well as in therapeutic settings, where cells transfected in vitro are reapplied to the patient. Direct in vivo transfection has been achieved for skin cells using ballistic DNA-immunization and for the liver using hydrodynamic transfection by intravenous bolus injections of DNA in a large volume. In general, however, in vivo transfection efficiencies are low. The unusually long CDR3 of many camelid and shark antibodies could potentially open the possibility of creating synthetic peptide mimetics [61]. In a recent proof-of-principle study, a peptide derived from the CDR3 of the lysozyme blocking camel Ab cabLys3 (Fig. 3b) was shown to block lysozyme activity. However, much higher concentrations of this "peptibody" were required for inhibiting lysozyme than of the parental VHH [62]. Nevertheless, it is possible that synthetic peptibodies can be delivered more efficiently to the cytosol than larger sdAbs.

\section{Molecular assembly vaccines}

The higher immunogenicity of repetitive proteins could potentially be exploited also for increasing vaccine efficiency. Lumazine synthase from Brucella abortus spontaneously assembles into pentamers and decamers and shows very high immunogenicity even during primary immunizations [63]. In our own labs, we have raised sdAbs specific for lumazine synthase as tools to interfere with flavin biosynthesis in these pathogenic bacteria. These sdAbs might also be useful for converting a monomeric antigen into a multimeric format by providing a "piggyback" link to lumazine synthase, e.g., following cloning and recombinant production of an sdAb-antigen fusion protein (Fig. 7i). We hypothesize that the antigen's immunogenicity will be much higher in such a molecular assembly vaccine than in its original monomeric format.

sdAbs as tools for molecular mimicry

Antibodies directed against the antigen-binding paratope (idiotype) of another antibody are called anti-idiotypic antibodies (anti-Id Abs) (Fig. 7j). Such anti-Id Abs compete with the antigen for binding to the parental $A b$ and are thought to share partially or completely the reactive surface with the combining site, thus mimicking the structure of the antigen. In a proof-of-principle study, two sdAbs were selected from a llama immunized with a DNA-specific monoclonal antibody (ED84) [64]. These sdAbs were found to compete with a double-stranded DNA oligonucleotide for binding to ED84 and thus bear a functional mimicry of the DNA. In a similar approach anti-idiotypic VNARs were selected from a semi-synthetic phage display library against the idiotype of a monoclonal antibody specific for a linear tripeptide epitope in the Plasmodium falciparum apical membrane protein antigen-1 (AMA-1). These VNARs showed enhanced affinity compared to the parental antigen [65].

\section{Single domain antibodies in infection}

Antibodies have a longstanding history as therapeutic agents against toxins and pathogens. The first Nobel Prize in Medicine was awarded in 1901 to Emil von Behring for his discovery of passive immune therapy as a cure for diphtheria, a devastating epidemic disease in those days. The molecular structure of antibodies, the effective agent in the diphtheria antiserum that von Behring obtained from immunized horses, was solved only half a century later. Today, another half century later, we have the tools for cloning and reformatting antibodies from different animals and even for assembling antibodies semi-synthetically. sdAbs, in particular, hold great promise to fulfill Paul Ehrlich's vision of "magic bullets" for combating toxins and pathogens [66, 67].

Targeting protein toxins and poisons with sdAbs

Some of the most potent toxins found in nature are enzymes, including numerous proteins secreted by bacteria and the venomous organs of snakes and scorpions. 
Table 2 Applications of sdAbs in infection

\begin{tabular}{|c|c|c|c|}
\hline Target & Application & Source of sdAb & Reference \\
\hline \multicolumn{4}{|l|}{ Toxins } \\
\hline Salmonella SpvB toxin & Neutralization & Immune llama & Alzogaray et al. (unpublished) \\
\hline $\begin{array}{l}\text { Cholera toxin, } \\
\text { staphylococcus } \\
\text { enterotoxin A, } \\
\text { ricin, botulinum } \\
\text { neurotoxin A }\end{array}$ & Biosensor & $\begin{array}{l}\text { Non-immune } \\
\text { llama and } \\
\text { non-immune } \\
\text { shark }\end{array}$ & {$[69-71,119]$} \\
\hline LPS & Depletion of endotoxin & Non-immune llama & {$[72]$} \\
\hline Scorpion toxin & Neutralization & $\begin{array}{l}\text { Immune camel } \\
\text { and dromedary }\end{array}$ & {$[74,77]$} \\
\hline Scorpion/conus toxins & Neutralization & Immune shark & Licea et al. (unpublished) \\
\hline Alpha-cobrotoxin & Antivenom development & Non-immune llama & {$[76]$} \\
\hline Mycotoxin & Detecting toxin contamination & Immune llama & {$[78]$} \\
\hline \multicolumn{4}{|l|}{ Viruses } \\
\hline HIV env & Neutralization & Immune llama & {$[84]$} \\
\hline Rotavirus, gp6 & Absorption of virus on lactobacillus & Immune llama & {$[17,85,120]$} \\
\hline FMDV & Neutralization & Immune llama & {$[86,87]$} \\
\hline Hepatitis B & Blocking virus secretion & Immune llama & {$[20]$} \\
\hline $\begin{array}{l}\text { Lactococcus } \\
\text { phage receptor } \\
\text { binding protein }\end{array}$ & Protect milk fermentation & Immune llama & {$[88,89]$} \\
\hline Porcine retrovirus & $\begin{array}{l}\text { Neutralize endogenous } \\
\text { retrovirus in } \\
\text { transgenic pigs }\end{array}$ & Immune llama & [91] \\
\hline Marburg virus & Biosensor/diagnosis & Non-immune llama & [92] \\
\hline \multicolumn{4}{|l|}{ Bacteria } \\
\hline Streptococcus mutans & Reduce dental caries & Immune llama & {$[94,95]$} \\
\hline E. coli $\mathrm{F} 4$ fimbriae & Treat pig diarrhea & Immune llama & {$[93,121]$} \\
\hline EspI:EpsJ pseudopilin & Chaperone assisted crystallography & Immune llama & {$[97]$} \\
\hline GspD secretin & Chaperone assisted crystallography & Immune llama & [96] \\
\hline$\beta$-lactamase & Antibiotic enhancement & Immune dromedary & {$[52,99]$} \\
\hline \multicolumn{4}{|l|}{ Parasites } \\
\hline $\begin{array}{l}\text { Variable surface } \\
\text { glycoprotein } \\
\text { (oligomannose) }\end{array}$ & Trypanosome drug delivery & Immune dromedary & {$[100,101]$} \\
\hline Trans-sialidase & Trypanosomiasis diagnosis & Immune llama & [103] \\
\hline Trypanosomes & Infectome tools & Immune dromedary & {$[102]$} \\
\hline AMA1 & Malaria diagnosis & Immune shark & [122] \\
\hline Taenia solium & Tapeworm diagnosis & Immune dromedary & {$[104]$} \\
\hline
\end{tabular}

Toxin-specific sdAbs have been isolated from immune llama phage display libraries (Table 2). Like murine ART2.2, the SpvB Salmonella toxin is an ADP-ribosyltransferase that transfers ADP-ribose from NAD onto specific amino acid side chains of proteins [26, 31] (Fig. 8c). Upon translocation into the cytosol of animal cells, SpvB blocks cytoskeletal functions by ADP-ribosylating actin and thereby blocking its polymerization. From an SpvBimmunized llama, we have isolated SpvB-blocking sdAbs that block SpvB enzymatic activity at a 1:1 molar ratio.
When expressed as intrabodies in transfected cells, these nanobodies effectively block SpvB-mediated disruption of the cell cytoskeleton (Fig. 7h). Several other important human pathogens, including $V$. cholera, B. pertussis, and S. enterica, which induce disease by secreting toxin ARTs [68] might similarly be suitable for targeting by enzymeblocking sdAbs.

Bacterial toxin-specific sdAbs have been successfully isolated from naïve llama and naïve shark libraries, including sdAbs specific for cholera toxin, staphylococcal 
enterotoxin B, and botulinum neurotoxin A [69-71]. It is likely that many of these sdAbs possess only low affinities and their neutralization capacities have not been reported. Notwithstanding, some have been shown useful for diagnostic purposes, e.g., upon conversion to a multivalent format by the attachment to beads. These sdAbs, thus, hold promise for biosensor applications.

Endotoxin, i.e., lipopolysaccharide (LPS), released from the outer membrane of gram-negative bacteria into the blood circulation after infection can mediate severe septic shock. LPS-specific sdAbs, selected from a non-immune llama VHH phage display library, effectively removed LPS from serum and other aqueous solutions [72].

Venom of snakes, scorpions, spiders, and frogs represent significant threats to human health in many countries. Intravenous administration of conventional IgG or Fab fragments prepared from immunized horses or sheep can provide alleviation for some cases of systemic envenoming and recent studies indicate that corresponding hcAbs prepared from immunized camels and llamas are similarly or even more effective [73-75]. An sdAb against alpha cobra toxin was derived from a naïve llama phage display library and engineered into a pentameric format by genetic fusion to the non-toxic B-subunit of verotoxin, yielding a reagent with higher avidity and neutralization capacity [76]. An $\mathrm{sdAb}$ directed against scorpion toxin $\left(\mathrm{NbAahI}^{\prime} 22\right)$ derived from an immunized dromedary showed potent neutralizing capacity already in a monovalent format which was enhanced further upon conversion into a bivalent heavychain format by genetic fusion to the Fc region of human IgG1 (Fig. 7f) [77].

Targeting small molecule toxins and other haptens with sdAbs

Fungi secrete small chemical compounds that can be toxic to animal cells. Recently, an sdAb (NAT-267) was developed from an immunized llama against BSA-conjugated Deoxynivalenol (300 Da), a mycotoxin produced by common grain molds [78]. The high affinity of this sdAb paves way for developing low-cost toxin detection systems and potentially also for immunomodulation of Deoxynivalenol's cytotoxic effects. Other haptens have been targeted by sdAbs, including red azo dyes (728 Da) found in red wine (with the potential use of targeting enzymes to stains during washing) [79], caffeine (with the potential use of detecting caffeine in beverages) [80], the explosive TNT (biosensor) [81], and the chemotherapeutic agent methotrexate (MTX, $454 \mathrm{Da}$ ) [82]. Antihapten sdAbs have potential in cancer therapy, for e.g., in a bi-specific format to help target radiolabeled haptens to tumors for imaging and radioimmunotherapy [83].
Targeting viruses with sdAbs

Viruses often use "hidden" epitopes on the capsid or envelope, e.g., deep invaginations or canyons, for docking onto receptors on host cells. Such epitopes are hidden from the large and typically flat antigen-binding sites of conventional antibodies. Moreover, these epitopes are often well conserved between viruses that use the same receptor while more protruded regions of the capsid/envelope change rapidly, helping the virus to escape from immune attack. Analogous to the active site crevice of enzymes, these canyons on the viral surface are usually inaccessible to conventional antibodies, but constitute preferential targets for singlechain antibodies from camelids and sharks. Numerous viruses are being targeted by sdAbs, among these HIV, for which crosstype-specific HIV-neutralizing sdAbs were recently derived from an immunized llama [84].

Several groups have succeeded in raising sdAbs directed against rotavirus, the causative agent of severe childhood diarrhea. Immunization of a llama with a more internally located capsid protein of rotavirus yielded sdAbs that recognize and neutralize several different strains of rotavirus [85]. In a mouse model, oral application of these sdAbs provided significant amelioration of diarrhea. In an elegant approach to increase the local dose of rotavirus-absorbing sdAbs, a rotavirus-specific sdAb derived from an immunized camel was cloned in-frame with a lactobacillus cell surface protease into a lactobacillus expression vector [17]. Transformation yielded recombinant versions of this commensal gut bacterium that express a high density of rotavirus-specific sdAbs on the cell surface (dubbed lactobodies) (Fig. 7g). Feeding of the recombinant lactobacillus also provided significant protection from rotavirus-mediated disease.

Foot and mouth disease virus (FMDV) neutralizing sdAbs were isolated from a llama immunized with a crude extract of FMDV-infected BHK cells [86]. The in vivo half-life of these sdAbs was enhanced by genetic fusion to a second VHH specific for pig IgG. Intramuscular administration of these bispecific sdAbs significantly reduced viremia in subsequently infected piglets, but did not prevent transmission of FMDV [87]. Virus-neutralizing sdAbs have also been developed for industrial applications, e.g., for the neutralization of phages that infect lactobacilli and thereby present a significant threat in the milk and cheese industry [88-90].

sdAbs have been generated and applied successfully also against intracellular viral proteins. Porcine endogenous retroviruses (PERV) reside within the pig genome and are capable of transfecting human cells in vitro, thereby presenting a potential hazard for xenotransplantation. An $\mathrm{sdAb}$, isolated from a llama immunized with the $60 \mathrm{kD} \mathrm{Gag}$ protein of porcine endogenous retrovirus [91] and 
expressed as an intrabody, effectively inhibited production of virus particles. Transgenic expression of such sdAbs could contribute to solving safety problems associated with PERVs. Similarly, an sdAb derived from a llama immunized with hepatitis B virus particles was converted into a format targeted to the lumen of the endoplasmic reticulum (ER) by fusion to the KDEL ER-retention signal. Cells cotransfected with expression constructs for this sdAb reagent and hepatitis $B$ showed enhanced intracellular retention and correspondingly diminished secretion of hepatitis B particles. In mouse models, the rapid intravenous bolus injection of an expression vector for the hepatitis-specific sdAb in a large volume of buffer resulted in efficient hydrodynamic transfection of liver cells and a therapeutic benefit [20].

Four sdAbs were selected from a non-immune llama library by panning against immobilized Marburg virus [92]. Even though these sdAbs from a naïve library displayed only low affinities, a sensitive diagnostic assay system could be developed by converting the nucleoprotein-specific sdAbs into multivalent formats. Capture of the virus was achieved by simple immobilization of the sdAbs on the wells of an ELISA plate. Detection was achieved upon genetic fusion to bacterial alkaline phosphatase which forms homo-dimers, thus yielding a bivalent enzyme-linked detection reagent. The assay allows detection of three Marburg virus variants without cross reactivity to the four Ebola virus species.

Targeting pathogenic bacteria with sdAbs

Single domain antibodies have also been raised against bacterial surface proteins with the goals of blocking attachment of bacteria to host cells and/or for more effective delivery of pro-drugs. A VHH (K609) against E. coli F4 fimbriae, applied at high doses, reduced E. coli induced diarrhea in piglets. However, when applied orally, a large portion of this $\mathrm{sdAb}$ was found to be proteolytically degraded in the upper gastrointestinal tract. Proteolytic degradation is mediated by pepsin in the stomach and by trypsin and chymotrypsin in the duodenum [93]. Using a DNA-shuffling strategy involving the random recombination of gene segments obtained from VHH K609 and two other F4-specific VHHs, following DNA fragmentation and PCR amplification, a variant VHH (K922) was selected that exhibited $>100$-fold increase in resistance to in vitro degradation by gastric and jejunal fluid.

Streptococcus mutans, the main cause of dental caries, achieves virulence in part via its ability to adhere to and to accumulate on tooth surfaces. An sdAb (S36-VHH) was developed from a llama immunized with a mixture of disrupted and intact $S$. mutans and genetically fused to fungal glucose oxidase, a homo-dimeric $150 \mathrm{kD}$ enzyme that produces hydrogen peroxide $\left(\mathrm{H}_{2} \mathrm{O}_{2}\right)$ in the presence of glucose and oxygen. The fusion protein was readily produced in yeast [94]. In a rat model of strong cariogenic challenge, daily application of the sdAb monomer as well as the VHHglucose oxidase fusion protein resulted in a reduced level of bacterial recovery 21 days after infection, albeit not at a statistically significant level due to large variation in bacterial recovery [95].

sdAbs have also been used successfully to improve the probability of obtaining crystals for proteins that are difficult to crystallize. An sdAb can assist the crystallization process by stabilizing the protein of interest and/or by creating additional crystal contact surface. VHHs isolated from immunized llamas were used to assist the crystallization of major components of the type 2 secretion system of enteropathogenic E. coli and Vibrio. This 11 component extracellular protein secretion system is used for secretion of cholera toxin and heat labile enterotoxin [96, 97]. Similarly, the phage P2 receptor-binding protein was successfully co-crystallized with an sdAb [98].

Many bacteria secrete enzymes that inactivate antibiotics as an efficient escape mechanism from antibiotic therapy. Enzyme-blocking sdAbs were generated from immunized dromedaries that effectively block $\beta$-lactamases which catalyze the hydrolysis of $\beta$-lactam antibiotics [99] with the potential utility of improving antibiotic therapies.

Targeting parasites with sdAbs

Single domain antibodies are also being developed as antiparasite reagents. Trypanosomes are coated with variable surface glycoproteins (VSGs) and evade host immune responses by changing the VSGs that cover the entire membrane. Owing to their smaller size, sdAbs might better penetrate the VSG coat to gain access to conserved epitopes that are inaccessible for conventional antibodies. An sdAb (NbAn33) recognizing an oligomannose cryptic epitope on trypanosomes was isolated from a dromedary immunized with purified VSG [100]. In contrast to conventional antibodies and lectins, this sdAb was able to penetrate the dense VSG coat. A fluorochrome-conjugate of this $\mathrm{sdAb}$ allowed the direct sensitive detection of parasites in blood smears. Immunotoxins were generated by genetically fusing this $\operatorname{sdAb}(\mathrm{An} 33)$ to either $\beta$-lactamase or a truncated version of the pore forming human serum protein apolipoprotein L-I (Fig. 7c). Fusion to $\beta$-lactamase, which can convert a cephalosporin-based prodrug into the potent toxic phenylenediamine mustard (PDM), yielded a conjugate with both, retained capacity to bind to trypanosomes and retained enzyme activity. Sub-lethal doses of the pro-drug proved highly toxic to conjugate treated parasites. Genetic fusion to a truncated form of human apolipoprotein L-I yielded an immunotoxin with lytic activity against a range of different trypanosomes [101]. In a mouse model the 
VHH-apoL-I fusion protein had curative and alleviating effects on acute and chronic infections with trypanosomes. Further sdAbs directed against VSG and other trypanosome proteins were selected from an immune library obtained from a dromedary infected with live trypanosomes [102]. We have also obtained and characterized sdAbs directed against trans-sialidase from Trypanosoma cruzi [103]. Even though these sdAbs are unable to interfere with the crucial role of trans-sialidase in cell entry of the parasite, they served as a tool to unmask a novel strategy of $T$. cruzi to evade the host immune system.

The larval form of the pork tapeworm Taenia solium is the cause of cysticercosis, the most common parasitic infection of the central nervous system and a major cause of epilepsy in developing countries. Immunization of two dromedaries with $T$. solium extracts yielded an $\operatorname{sdAb}$ (Nbsol52) recognizing the $14 \mathrm{kD}$ diagnostic glycoprotein Ts14 [104]. This sdAb showed subnanomolar affinity for Ts14 and was found capable of capturing antigen present in the serum of infected pigs. Further studies are required to assess the potential therapeutic use of such sdAbs in cysticercosis. Malassezia furfur is a fungus implicated in dandruff. sdAbs specific for a cell wall protein of M. furfur were derived from an immunized llama [105]. Some of these sdAbs were found to be resistant to detergents in shampoo and may provide a possible antifungal additive to shampoos.

\section{Conclusions and perspectives}

Approximately 15 years have passed since the serendipitous discovery of the peculiar hcAbs in camels [2], followed by the elucidation of the similar, heavy-chain-only structure of shark new antigen receptors [106]. The remarkable proof-of-principle studies published since then point to a tremendous diagnostic and therapeutic potential of single domain antibody reagents derived from these hcAbs. Numerous sdAbs have already proven useful for basic research and as improved diagnostic and biosensor tools. In vivo studies have underscored the favorable biodistribution of sdAbs, including deep penetration into dense tissues and rapid elimination via the kidney. These features make sdAbs particularly amenable for imaging of tumors and for the delivery of cytotoxic agents. sdAbs should also prove useful for neutralizing soluble extracellular proteins including toxins, cytokines, and blood clotting components. The capacity of sdAbs to block leukocyte ecto-enzymes indicates their potential utility as anti-inflammatory and immune modulating agents.

Notwithstanding, a number of obstacles still have to be surmounted before widespread clinical application of sdAbs becomes possible. A major concern for repeated and/ or long-term clinical use is the potential immunogenicity of $\mathrm{sdAb}$ reagents. While the systemic application of small monovalent sdAbs seems to induce little, if any, neutralizing antibody responses, protein immunogenicity generally increases with size and complexity. This will likely pertain also for the fusion constructs illustrated in Fig. 7. Enhanced immunogenicity, of course, is desired in case of vaccines, but not for therapeutic applications. Recently, a strategy to humanize camelid $\mathrm{sdAb}$ was described in which the surface of a camel sdAb was reshaped by mutating 12 out of the 14 surface-exposed residues in which camel sdAbs differ from human $\mathrm{VH}$ domains to the corresponding human residue [107]. It remains to be determined whether these humanized VHH display lower immunogenicity than the camelid $\mathrm{sdAb}$. Immunogenicity is a particular concern for intravenous and other systemic injections, but may be less problematic for other routes of application, in particular gastrointestinal and intraocular injections. Moreover, single injections, such as for the treatment of acute toxin exposure, are less immunogenic than the repeated applications required for the treatment of chronic inflammatory diseases.

For intracellular targets, more efficient delivery tools will need to be developed for sdAbs to reach the cytosol and other intracellular compartments. Transfection-mediated expression of intracellular sdAbs appears to be a feasible strategy for cell/gene therapy regiments and for transgenic plants and animals. For humans, however, in vivo transfection so far seems feasible only for accessible tissues, such as skin and possibly the liver. Considering that antigen-binding of many camelid and shark sdAbs is mediated in large part by their long CDR3, it may be possible in some cases to develop peptide-mimetics of the antigen-binding principle [61].

Presently, the immunization of llamas and dromedaries is cumbersome and costly in comparison to immunization of smaller animals. Transgenic mice expressing camelid antibodies, analogous to the transgenic mice expressing human antibodies [22], could provide more economic sources of sdAbs. A recent study provided a first proof-ofprinciple that single-chain antibodies, indeed, can be correctly assembled and expressed by B-cells of transgenic mice carrying a mini-Ig construct encoding a dromedary VHH and the Fc-domain of human IgG1 [108, 109].

Assuming that progress will continue at the present pace, it is likely that the future repertoire of researchers and clinicians will include a battery of $\mathrm{sdAb}$ reagents directed against cytokines, ecto-enzymes, tumor antigens, toxins, and microbes.

Acknowledgments This work was supported by grants No310/4 and No310/5 from the Deutsche Forschungsgemeinschaft and the Bundesministerium für Wirtschaftliche Zusammenarbeit to FKN and FG, by grant 3/74 from the Werner Otto Stiftung to FKN and JW, by a stipend from the Studienstiftung des Deutschen Volkes to MU, and by a grant 
from the Deutsche Akademische Austauschdienst to KJ, FH, and AL. We thank Drs. Johannes Koch and Hans-Willi Mittrücker, Hamburg, for critical reading of the manuscript. JW prepared the figures, FKN wrote the paper. All authors read and edited the paper and approved the final version. The authors disclose the following financial interests: FKN and FH receive a share of antibody sales via Analytical Services $\mathrm{GmbH}$, a wholly owned subsidiary of the University Medical Center Hamburg Eppendorf. FG is co-founder of Immunova, a wholly owned subsidiary of the Instituto Leloir, that provides molecular assembly vaccines and llama immunizations.

Open Access This article is distributed under the terms of the Creative Commons Attribution Noncommercial License which permits any noncommercial use, distribution, and reproduction in any medium, provided the original author(s) and source are credited.

\section{References}

1. Brekke OH, Sandlie I (2003) Therapeutic antibodies for human diseases at the dawn of the twenty-first century. Nat Rev Drug Discov 2(1):52-62. doi:10.1038/nrd984

2. Hamers-Casterman C, Atarhouch T, Muyldermans S, Robinson G, Hamers C, Songa EB, Bendahman N, Hamers R (1993) Naturally occurring antibodies devoid of light chains. Nature 363(6428):446-448. doi:10.1038/363446a0

3. Muyldermans S (2001) Single domain camel antibodies: current status. J Biotechnol 74(4):277-302

4. Holliger P, Hudson PJ (2005) Engineered antibody fragments and the rise of single domains. Nat Biotechnol 23(9):1126-1136. doi: $10.1038 /$ nbt1 142

5. Desmyter A, Transue TR, Ghahroudi MA, Thi MH, Poortmans F, Hamers R, Muyldermans S, Wyns L (1996) Crystal structure of a camel single-domain $\mathrm{VH}$ antibody fragment in complex with lysozyme. Nat Struct Biol 3(9):803-811. doi:10.1038/nsb0996803

6. De Genst E, Silence K, Decanniere K, Conrath K, Loris R, Kinne J, Muyldermans S, Wyns L (2006) Molecular basis for the preferential cleft recognition by dromedary heavy-chain antibodies. Proc Natl Acad Sci USA 103(12):4586-4591. doi:10.1073/ pnas.0505379103

7. Wu TT, Johnson G, Kabat EA (1993) Length distribution of CDRH3 in antibodies. Proteins 16(1):1-7. doi:10.1002/prot. 340160102

8. Harmsen MM, De Haard HJ (2007) Properties, production, and applications of camelid single-domain antibody fragments. Appl Microbiol Biotechnol 77(1):13-22. doi:10.1007/s00253-007$1142-2$

9. Pini A, Bracci L (2000) Phage display of antibody fragments. Curr Protein Pept Sci 1(2):155-169. doi:10.2174/138920300 3381397

10. Hoogenboom HR (2005) Selecting and screening recombinant antibody libraries. Nat Biotechnol 23(9):1105-1116. doi:10. 1038/nbt1126

11. Cortez-Retamozo V, Lauwereys M, Hassanzadeh Gh G, Gobert M, Conrath K, Muyldermans S, De Baetselier P, Revets H (2002) Efficient tumor targeting by single-domain antibody fragments of camels. Int J Cancer 98(3):456-462. doi:10.1002/ijc.10212

12. Dumoulin M, Last AM, Desmyter A, Decanniere K, Canet D, Larsson G, Spencer A, Archer DB, Sasse J, Muyldermans S, Wyns L, Redfield C, Matagne A, Robinson CV, Dobson CM (2003) A camelid antibody fragment inhibits the formation of amyloid fibrils by human lysozyme. Nature 424(6950):783-788. doi:10.1038/nature01870
13. Conrath EK, Lauwereys M, Wyns L, Muyldermans S (2001) Camel single-domain antibodies as modular building units in bispecific and bivalent antibody constructs. J Biol Chem 276(10):7346-7350. doi:10.1074/jbc.M007734200

14. Rothbauer U, Zolghadr K, Tillib S, Nowak D, Schermelleh L, Gahl A, Backmann N, Conrath K, Muyldermans S, Cardoso MC, Leonhardt $\mathrm{H}$ (2006) Targeting and tracing antigens in live cells with fluorescent nanobodies. Nat Methods 3(11):887-889. doi: $10.1038 /$ nmeth953

15. Olichon A, Surrey T (2007) Selection of genetically encoded fluorescent single domain antibodies engineered for efficient expression in Escherichia coli. J Biol Chem 282(50):3631436320. doi:10.1074/jbc.M704908200

16. Coppieters K, Dreier T, Silence K, De Haard H, Lauwereys M, Casteels P, Beirnaert E, Jonckheere H, Van de Wiele C, Staelens L, Hostens J, Revets H, Remaut E, Elewaut D, Rottiers P (2006) Formatted anti-tumor necrosis factor alpha VHH proteins derived from camelids show superior potency and targeting to inflamed joints in a murine model of collagen-induced arthritis. Arthritis Rheum 54(6):1856-1866. doi:10.1002/art.21827

17. Pant N, Hultberg A, Zhao Y, Svensson L, Pan-Hammarstrom Q, Johansen K, Pouwels PH, Ruggeri FM, Hermans P, Frenken L, Boren T, Marcotte H, Hammarstrom L (2006) Lactobacilli expressing variable domain of llama heavy-chain antibody fragments (lactobodies) confer protection against rotavirus-induced diarrhea. J Infect Dis 194(11):1580-1588. doi:10.1086/508747

18. Gueorguieva D, Li S, Walsh N, Mukerji A, Tanha J, Pandey S (2006) Identification of single-domain, Bax-specific intrabodies that confer resistance to mammalian cells against oxidativestress-induced apoptosis. FASEB J 20(14):2636-2638. doi:10. 1096/fj.06-6306fje

19. Jobling SA, Jarman C, Teh MM, Holmberg N, Blake C, Verhoeyen ME (2003) Immunomodulation of enzyme function in plants by single-domain antibody fragments. Nat Biotechnol 21(1):77-80. doi:10.1038/nbt772

20. Serruys B, Van Houtte F, Verbrugghe P, Leroux-Roels G, Vanlandschoot P (2009) Llama-derived single-domain intrabodies inhibit secretion of hepatitis $\mathrm{B}$ virions in mice. Hepatology 49(1):39-49. doi:10.1002/hep.22609

21. Feldmann M (2002) Development of anti-TNF therapy for rheumatoid arthritis. Nat Rev Immunol 2(5):364-371. doi:10.1038/ nri802

22. Lonberg N (2008) Fully human antibodies from transgenic mouse and phage display platforms. Curr Opin Immunol 20(4):450-459. doi:10.1016/j.coi.2008.06.004

23. Drucker A, Skedgel C, Virik K, Rayson D, Sellon M, Younis T (2008) The cost burden of trastuzumab and bevacizumab therapy for solid tumours in Canada. Curr Oncol 15(3):136-142. doi:10.3747/co.v15i3.249

24. Goding JW, Howard MC (1998) Ecto-enzymes of lymphoid cells. Immunol Rev 161:5-10. doi:10.1111/j.1600-065X.1998. tb01567.x

25. Salmi M, Jalkanen S (2005) Cell-surface enzymes in control of leukocyte trafficking. Nat Rev Immunol 5(10):760-771. doi:10. 1038/nri1705

26. Corda D, Di Girolamo M (2003) Functional aspects of protein mono-ADP-ribosylation. EMBO J 22(9):1953-1958. doi:10. 1093/emboj/cdg209

27. Zolkiewska A (2005) Ecto-ADP-ribose transferases: cell-surface response to local tissue injury. Physiology (Bethesda) 20:374381. doi:10.1152/physiol.00028.2005

28. Di Virgilio F, Chiozzi P, Ferrari D, Falzoni S, Sanz JM, Morelli A, Torboli M, Bolognesi G, Baricordi OR (2001) Nucleotide receptors: an emerging family of regulatory molecules in blood cells. Blood 97(3):587-600. doi:10.1182/blood.V97.3.587 
29. Koch-Nolte F, Reyelt J, Schössow B, Schwarz N, Scheuplein F, Rothenburg S, Haag F, Alzogaray V, Cauerhff A, Goldbaum FA (2007) Single domain antibodies from llama effectively and specifically block T cell ecto-ADP-ribosyltransferase ART2.2 in vivo. FASEB J 21(13):3490-3498. doi:10.1096/fj.07-8661com

30. Adriouch S, Hubert S, Pechberty S, Koch-Nolte F, Haag F, Seman M (2007) NAD+ released during inflammation participates in T cell homeostasis by inducing ART2-mediated death of naive T cells in vivo. J Immunol 179(1):186-194

31. Koch-Nolte F, Adriouch S, Bannas P, Krebs C, Scheuplein F, Seman M, Haag F (2006) ADP-ribosylation of membrane proteins: unveiling the secrets of a crucial regulatory mechanism in mammalian cells. Ann Med 38(3):188-199. doi:10.1080/07853 890600655499

32. Scheuplein F, Schwarz N, Adriouch S, Krebs C, Bannas P, Rissiek B, Seman M, Haag F, Koch-Nolte F (2009) NAD+ and ATP released from injured cells induce P2X7-dependent shedding of CD62L and externalization of phosphatidylserine by murine T cells. J Immunol 182(5):2898-2908. doi:10.4049/ jimmunol.0801711

33. Adriouch S, Bannas P, Schwarz N, Fliegert R, Guse AH, Seman M, Haag F, Koch-Nolte F (2008) ADP-ribosylation at R125 gates the P2X7 ion channel by presenting a covalent ligand to its nucleotide binding site. FASEB J 22(3):861-869. doi:10.1096/fj.07$9294 \mathrm{com}$

34. Seman M, Adriouch S, Scheuplein F, Krebs C, Freese D, Glowacki G, Deterre P, Haag F, Koch-Nolte F (2003) NADinduced $\mathrm{T}$ cell death: ADP-ribosylation of cell surface proteins by ART2 activates the cytolytic P2X7 purinoceptor. Immunity 19(4):571-582. doi:10.1016/S1074-7613(03)00266-8

35. Ghetie V, Popov S, Borvak J, Radu C, Matesoi D, Medesan C, Ober RJ, Ward ES (1997) Increasing the serum persistence of an IgG fragment by random mutagenesis. Nat Biotechnol 15(7):637-640. doi:10.1038/nbt0797-637

36. Behar G, Sibéril S, Groulet A, Chames P, Pugnière M, Boix C, Sautès-Fridman C, Teillaud JL, Baty D (2008) Isolation and characterization of anti-FcgammaRIII (CD16) llama single-domain antibodies that activate natural killer cells. Protein Eng Des Sel 21(1):1-10. doi:10.1093/protein/gzm064

37. Groot AJ, Khattabi ME, Sachs N, van der Groep P, van der Wall E, van Diest PJ, Sonnenberg A, Verrips CT, Vooijs M (2009) Reverse proteomic antibody screening identifies anti adhesive VHH targeting VLA-3. Mol Immunol 46(10):2022-2028

38. Muruganandam A, Tanha J, Narang S, Stanimirovic D (2002) Selection of phage-displayed llama single-domain antibodies that transmigrate across human blood-brain barrier endothelium. FASEB J 16(2):240-242

39. Abulrob A, Sprong H, Van Bergen en Henegouwen P, Stanimirovic D (2005) The blood-brain barrier transmigrating single domain antibody: mechanisms of transport and antigenic epitopes in human brain endothelial cells. J Neurochem 95(4):12011214. doi:10.1111/j.1471-4159.2005.03463.x

40. Cortez-Retamozo V, Backmann N, Senter PD, Wernery U, De Baetselier P, Muyldermans S, Revets H (2004) Efficient cancer therapy with a nanobody-based conjugate. Cancer Res 64(8):2853-2857. doi:10.1158/0008-5472.CAN-03-3935

41. Omidfar K, Rasaee MJ, Modjtahedi H, Forouzandeh M, Taghikhani M, Golmakani N (2004) Production of a novel camel single-domain antibody specific for the type III mutant EGFR. Tumour Biol 25(5-6):296-305. doi:10.1159/00008 1395

42. Roovers R, Laeremans T, Huang L, De Taeye S, Verkleij A, Revets H, de Haard HJ, van Bergen en Henegouwen PM (2007) Efficient inhibition of EGFR signaling and of tumour growth by antagonistic anti-EFGR nanobodies. Cancer Immunol Immunother 56(3):303-317. doi:10.1007/s00262-006-0180-4
43. Huang L, Gainkam LO, Caveliers V, Vanhove C, Keyaerts M, De Baetselier P, Bossuyt A, Revets H, Lahoutte T (2008) SPECT imaging with $99 \mathrm{mTc}$-labeled EGFR-specific nanobody for in vivo monitoring of EGFR expression. Mol Imaging Biol 10(3): $167-175$

44. Tijink BM, Laeremans T, Budde M, Stigter-van Walsum M, Dreier T, de Haard HJ, Leemans CR, van Dongen GA (2008) Improved tumor targeting of anti-epidermal growth factor receptor Nanobodies through albumin binding: taking advantage of modular Nanobody technology. Mol Cancer Ther 7(8):2288-2297. doi:10.1158/1535-7163.MCT-07-2384

45. Rahbarizadeh F, Rasaee MJ, Forouzandeh M, Allameh A, Sarrami R, Nasiry H, Sadeghizadeh M (2005) The production and characterization of novel heavy-chain antibodies against the tandem repeat region of MUC1 mucin. Immunol Invest 34(4):431-452. doi:10.1080/08820130500265356

46. Ahmadvand D, Rasaee MJ, Rahbarizadeh F, Mohammadi M (2008) Production and characterization of a high-affinity nanobody against human endoglin. Hybridoma (Larchmt) 27(5):353360. doi:10.1089/hyb.2008.0014

47. Palladino MA, Bahjat FR, Theodorakis EA, Moldawer LL (2003) Anti-TNF-alpha therapies: the next generation. Nat Rev Drug Discov 2(9):736-746. doi: $10.1038 /$ nrd 1175

48. Maass DR, Sepulveda J, Pernthaner A, Shoemaker CB (2007) Alpaca (Lama pacos) as a convenient source of recombinant camelid heavy chain antibodies (VHHs). J Immunol Methods 324(1-2):13-25. doi:10.1016/j.jim.2007.04.008

49. Wolfson W (2006) Ablynx makes nanobodies from llama bodies. Chem Biol 13(12):1243-1244. doi:10.1016/j.chembiol.2006.12.003

50. Hulstein JJ, de Groot PG, Silence K, Veyradier A, Fijnheer R, Lenting PJ (2005) A novel nanobody that detects the gain-offunction phenotype of von Willebrand factor in ADAMTS13 deficiency and von Willebrand disease type 2B. Blood 106(9):3035-3042. doi:10.1182/blood-2005-03-1153

51. Schenk D (2002) Amyloid-beta immunotherapy for Alzheimer's disease: the end of the beginning. Nat Rev Neurosci 3(10):824 828. doi:10.1038/nrn938

52. Dumoulin M, Conrath K, Van Meirhaeghe A, Meersman F, Heremans K, Frenken LG, Muyldermans S, Wyns L, Matagne A (2002) Single-domain antibody fragments with high conformational stability. Protein Sci 11(3):500-515. doi:10.1110/ps.34602

53. Lafaye P, Achour I, England P, Duyckaerts C, Rougeon F (2009) Single-domain antibodies recognize selectively small oligomeric forms of amyloid beta, prevent Abeta-induced neurotoxicity and inhibit fibril formation. Mol Immunol 46(4):695-704. doi:10.1016/j.molimm.2008.09.008

54. Habicht G, Haupt C, Friedrich RP, Hortschansky P, Sachse C, Meinhardt J, Wieligmann K, Gellermann GP, Brodhun M, Götz J, Halbhuber KJ, Röcken C, Horn U, Fändrich M (2007) Directed selection of a conformational antibody domain that prevents mature amyloid fibril formation by stabilizing Abeta protofibrils. Proc Natl Acad Sci USA 104(49):19232-19237. doi:10.1073/ pnas.0703793104

55. Klooster R, Maassen BT, Stam JC, Hermans PW, Ten Haaft MR, Detmers FJ, de Haard HJ, Post JA, Theo Verrips C (2007) Improved anti-IgG and HSA affinity ligands: clinical application of VHH antibody technology. J Immunol Methods 324(1-2):1-12. doi:10.1016/j.jim.2007.04.005

56. Cohen-Saidon C, Nechushtan H, Kahlon S, Livni N, Nissim A, Razin E (2003) A novel strategy using single-chain antibody to show the importance of $\mathrm{Bcl}-2$ in mast cell survival. Blood 102(7):2506-2512. doi:10.1182/blood-2002-12-3921

57. Avignolo C, Bagnasco L, Biasotti B, Melchiori A, Tomati V, Bauer I, Salis A, Chiossone L, Mingari MC, Orecchia P, Carnemolla B, Neri D, Zardi L, Parodi S (2008) Internalization via Antennapedia protein transduction domain of an $\mathrm{scFv}$ antibody 
toward c-Myc protein. FASEB J 22(4):1237-1245. doi:10.1096/ fj.07-8865com

58. Groot AJ, Verheesen P, Westerlaken EJ, Gort EH, van der Groep P, Bovenschen N, van der Wall E, van Diest PJ, Shvarts A (2006) Identification by phage display of single-domain antibody fragments specific for the ODD domain in hypoxia-inducible factor 1alpha. Lab Invest 86(4):345-356. doi:10.1038/labinvest.3700 395

59. Groot AJ, Gort EH, van der Wall E, van Diest PJ, Vooijs M (2008) Conditional inactivation of HIF-1 using intrabodies. Cell Oncol 30(5):397-409

60. Verheesen P, de Kluijver A, van Koningsbruggen S, de Brij M, de Haard HJ, van Ommen GJ, van der Maarel SM, Verrips CT (2006) Prevention of oculopharyngeal muscular dystrophyassociated aggregation of nuclear polyA-binding protein with a single-domain intracellular antibody. Hum Mol Genet 15(1):105-111. doi:10.1093/hmg/ddi432

61. Laune D, Molina F, Ferrieres G, Mani JC, Cohen P, Simon D, Bernardi T, Piechaczyk M, Pau B, Granier C (1997) Systematic exploration of the antigen binding activity of synthetic peptides isolated from the variable regions of immunoglobulins. J Biol Chem 272(49):30937-30944. doi:10.1074/jbc.272.49.30937

62. Marquardt A, Muyldermans S, Przybylski M (2006) A synthetic camel anti-lysozyme peptide antibody (peptibody) with flexible loop structure identified by high-resolution affinity mass spectrometry. Chem Eur J 12(7):1915-1923. doi:10.1002/chem. 200500785

63. Laplagne DA, Zylberman V, Ainciart N, Steward MW, Sciutto E, Fossati CA, Goldbaum FA (2004) Engineering of a polymeric bacterial protein as a scaffold for the multiple display of peptides. Proteins 57(4):820-828. doi:10.1002/prot.20248

64. Zarebski LM, Urrutia M, Goldbaum FA (2005) Llama single domain antibodies as a tool for molecular mimicry. J Mol Biol 349(4):814-824. doi:10.1016/j.jmb.2005.03.072

65. Simmons DP, Streltsov VA, Dolezal O, Hudson PJ, Coley AM, Foley M, Proll DF, Nuttall SD (2008) Shark IgNAR antibody mimotopes target a murine immunoglobulin through extended CDR3 loop structures. Proteins 71(1):119-130. doi:10.1002/ prot. 21663

66. Gura T (2002) Therapeutic antibodies: magic bullets hit the target. Nature 417(6889):584-586. doi:10.1038/417584a

67. Strebhardt K, Ullrich A (2008) Paul Ehrlich's magic bullet concept: 100 years of progress. Nat Rev Cancer 8(6):473-480. doi:10.1038/nrc2394

68. Aktories K, Just I (2000) Bacterial protein toxins. Springer Verlag, Berlin

69. Goldman ER, Anderson GP, Liu JL, Delehanty JB, Sherwood LJ, Osborn LE, Cummins LB, Hayhurst A (2006) Facile generation of heat-stable antiviral and antitoxin single domain antibodies from a semisynthetic llama library. Anal Chem 78(24):82458255. doi:10.1021/ac0610053

70. Liu JL, Anderson GP, Delehanty JB, Baumann R, Hayhurst A, Goldman ER (2007) Selection of cholera toxin specific IgNAR single-domain antibodies from a naïve shark library. Mol Immunol 44(7):1775-1783. doi:10.1016/j.molimm.2006.07.299

71. Goldman ER, Anderson GP, Conway J, Sherwood LJ, Fech M, Vo B, Liu JL, Hayhurst A (2008) Thermostable llama single domain antibodies for detection of botulinum A neurotoxin complex. Anal Chem 80(22):8583-8591. doi:10.1021/ac801 4774

72. El Khattabi M, Adams H, Heezius E, Hermans P, Detmers F, Maassen B, van der Ley P, Tommassen J, Verrips T, Stam J (2006) Llama single-chain antibody that blocks lipopolysaccharide binding and signaling: prospects for therapeutic applications. Clin Vaccine Immunol 13(10):1079-1086. doi:10.1128/ CVI.00107-06
73. Harrison RA, Wernery U (2007) The unique properties of camelid IgG have potential to improve the treatment of snake bite. J Camel Pract Res 14(1):15-16

74. Meddeb-Mouelhi F, Bouhaouala-Zahar B, Benlasfar Z, Hammadi M, Mejri T, Moslah M, Karoui H, Khorchani T, El Ayeb M (2003) Immunized camel sera and derived immunoglobulin subclasses neutralizing Androctonus australis hector scorpion toxins. Toxicon 42(7):785-791. doi:10.1016/j.toxicon.2003.10.021

75. Harrison RA, Hasson SS, Harmsen M, Laing GD, Conrath K, Theakston RD (2006) Neutralisation of venom-induced haemorrhage by IgG from camels and llamas immunised with viper venom and also by endogenous, non-IgG components in camelid sera. Toxicon 47(3):364-368. doi:10.1016/j.toxicon.2005.10.017

76. Stewart CS, MacKenzie CR, Hall JC (2007) Isolation, characterization and pentamerization of alpha-cobrotoxin specific singledomain antibodies from a naïve phage display library: preliminary findings for antivenom development. Toxicon 49(5):699-709. doi:10.1016/j.toxicon.2006.11.023

77. Hmila I, Abdallah RBA, Saerens D, Benlasfar Z, Conrath K, Ayeb ME, Muyldermans S, Bouhaouala-Zahar B (2008) VHH, bivalent domains and chimeric heavy chain-only antibodies with high neutralizing efficacy for scorpion toxin AahI' . Mol Immunol 45(14):3847-3856. doi:10.1016/j.molimm.2008.04.011

78. Doyle PJ, Arbabi-Ghahroudi M, Gaudette N, Furzer G, Savard ME, Gleddie S, McLean MD, MacKenzie CR, Hall JC (2008) Cloning, expression, and characterization of a single-domain antibody fragment with affinity for 15-acetyl-deoxynivalenol. Mol Immunol 45(14):3703-3713. doi:10.1016/j.molimm.2008. 06.005

79. Spinelli S, Frenken LG, Hermans P, Verrips T, Brown K, Tegoni M, Cambillau C (2000) Camelid heavy-chain variable domains provide efficient combining sites to haptens. Biochemistry 39(6):1217-1222. doi:10.1021/bi991830w

80. Ladenson RC, Crimmins DL, Landt Y, Ladenson JH (2006) Isolation and characterization of a thermally stable recombinant anti-caffeine heavy-chain antibody fragment. Anal Chem 78(13):4501-4508. doi:10.1021/ac058044j

81. Anderson GP, Goldman ER (2008) TNT detection using llama antibodies and a two-step competitive fluid array immunoassay. J Immunol Methods 339(1):47-54. doi:10.1016/j.jim.2008. 08.001

82. Alvarez-Rueda N, Behar G, Ferré V, Pugnière M, Roquet F, Gastinel L, Jacquot C, Aubry J, Baty D, Barbet J, Birklé S (2007) Generation of llama single-domain antibodies against methotrexate, a prototypical hapten. Mol Immunol 44(7):1680-1690. doi:10.1016/j.molimm.2006.08.007

83. Goldenberg DM, Sharkey RM, Paganelli G, Barbet J, Chatal JF (2006) Antibody pretargeting advances cancer radioimmunodetection and radioimmunotherapy. J Clin Oncol 24(5):823-834. doi:10.1200/JCO.2005.03.8471

84. Forsman A, Beirnaert E, Aasa-Chapman MM, Hoorelbeke B, Hijazi K, Koh W, Tack V, Szynol A, Kelly C, McKnight A, Verrips T, De Haard H, Weiss RA (2008) Llama antibody fragments with cross-subtype human immunodeficiency virus type 1 (HIV-1)neutralizing properties and high affinity for HIV-1 gp120. J Virol 82(24):12069-12081. doi:10.1128/JVI.01379-08

85. Garaicoechea L, Olichon A, Marcoppido G, Wigdorovitz A, Mozgovoj M, Saif L, Surrey T, Parreño V (2008) Llama-derived single-chain antibody fragments directed to rotavirus VP6 protein possess broad neutralizing activity in vitro and confer protection against diarrhea in mice. J Virol 82(19):9753-9764. doi:10.1128/JVI.00436-08

86. Harmsen MM, van Solt CB, Fijten HP, van Keulen L, Rosalia RA, Weerdmeester K, Cornelissen AH, De Bruin MG, Eble PL, Dekker A (2007) Passive immunization of guinea pigs with llama single-domain antibody fragments against foot-and-mouth 
disease. Vet Microbiol 120(3-4):193-206. doi:10.1016/j.vetmic. 2006.10.029

87. Harmsen MM, Fijten HP, Dekker A, Eblé PL (2008) Passive immunization of pigs with bispecific llama single-domain antibody fragments against foot-and-mouth disease and porcine immunoglobulin. Vet Microbiol 132(1-2):56-64. doi:10.1016/ j.vetmic.2008.04.030

88. Hultberg A, Tremblay D, De Haard H, Verrips T, Moineau S, Hammarström L, Marcotte H (2007) Lactobacilli expressing llama VHH fragments neutralise Lactococcus phages. BMC Biotechnol 7:58. doi:10.1186/1472-6750-7-58

89. de Haard HJ, Bezemer S, Ledeboer AM, Müller WH, Boender PJ, Moineau S, Coppelmans MC, Verkleij A, Frenken LG, Verrips CT (2005) Llama antibodies against a lactococcal protein located at the tip of the phage tail prevent phage infection. J Bacteriol 187(13):4531-4541. doi:10.1128/JB.187.13.45314541.2005

90. Ledeboer AM, Bezemer S, de Hiaard JJ, Schaffers IM, Verrips CT, van Vliet C, Düsterhöft EM, Zoon P, Moineau S, Frenken LG (2002) Preventing phage lysis of Lactococcus lactis in cheese production using a neutralizing heavy-chain antibody fragment from llama. J Dairy Sci 85(6):1376-1382

91. Dekker S, Toussaint W, Panayotou G, de Wit T, Visser P, Grosveld F, Drabek D (2003) Intracellularly expressed single-domain antibody against $\mathrm{p} 15$ matrix protein prevents the production of porcine retroviruses. J Virol 77(22):12132-12139. doi:10.1128/ JVI.77.22.12132-12139.2003

92. Sherwood LJ, Osborn LE, Carrion R, Patterson JL, Hayhurst A (2007) Rapid assembly of sensitive antigen-capture assays for Marburg virus, using in vitro selection of llama single-domain antibodies, at biosafety level 4. J Infect Dis 196(Suppl 2):S213S219. doi:10.1086/520586

93. Harmsen MM, van Solt CB, van Zijderveld-van Bemmel AM, Niewold TA, van Zijderveld FG (2006) Selection and optimization of proteolytically stable llama single-domain antibody fragments for oral immunotherapy. Appl Microbiol Biotechnol 72(3):544-551. doi:10.1007/s00253-005-0300-7

94. Szynol A, de Soet JJ, Sieben-van Tuyl E, Bos JW, Frenken LG (2004) Bactericidal effects of a fusion protein of llama heavychain antibodies coupled to glucose oxidase on oral bacteria. Antimicrob Agents Chemother 48(9):3390-3395. doi:10.1128/ AAC.48.9.3390-3395.2004

95. Krüger C, Hultberg A, Marcotte H, Hermans P, Bezemer S, Frenken LG, Hammarström L (2006) Therapeutic effect of llama derived VHH fragments against Streptococcus mutans on the development of dental caries. Appl Microbiol Biotechnol 72(4):732-737. doi:10.1007/s00253-006-0347-0

96. Korotkov KV, Pardon E, Steyaert J, Hol WG (2009) Crystal structure of the N-terminal domain of the secretin GspD from ETEC determined with the assistance of a nanobody. Structure 17(2):255-265. doi:10.1016/j.str.2008.11.011

97. Lam AY, Pardon E, Korotkov KV, Hol WG, Steyaert J (2009) Nanobody-aided structure determination of the EpsI:EpsJ pseudopilin heterodimer from Vibrio vulnificus. J Struct Biol 166(1):8-15. doi:10.1016/j.jsb.2008.11.008

98. Spinelli S, Desmyter A, Verrips CT, de Haard HJ, Moineau S, Cambillau C (2006) Lactococcal bacteriophage p2 receptor-binding protein structure suggests a common ancestor gene with bacterial and mammalian viruses. Nat Struct Mol Biol 13(1):85-89. doi:10.1038/nsmb1029

99. Conrath KE, Lauwereys M, Galleni M, Matagne A, Frère JM, Kinne J, Wyns L, Muyldermans S (2001) Beta-lactamase inhibitors derived from single-domain antibody fragments elicited in the camelidae. Antimicrob Agents Chemother 45(10):28072812. doi:10.1128/AAC.45.10.2807-2812.2001
100. Stijlemans B, Conrath K, Cortez-Retamozo V, Van Xong H, Wyns L, Senter P, Revets H, De Baetselier P, Muyldermans S, Magez S (2004) Efficient targeting of conserved cryptic epitopes of infectious agents by single domain antibodies. African trypanosomes as paradigm. J Biol Chem 279(2):1256-1261. doi:10.1074/jbc.M307341200

101. Baral TN, Magez S, Stijlemans B, Conrath K, Vanhollebeke B, Pays E, Muyldermans S, De Baetselier P (2006) Experimental therapy of African trypanosomiasis with a nanobody-conjugated human trypanolytic factor. Nat Med 12(5):580-584. doi: $10.1038 / \mathrm{nm} 1395$

102. Saerens D, Stijlemans B, Baral T, Nguyen Thi GT, Wernery U, Magez S, De Baetselier P, Muyldermans S, Conrath K (2008) Parallel selection of multiple anti-infectome Nanobodies without access to purified antigens. J Immunol Methods 329(1-2):138150. doi:10.1016/j.jim.2007.10.005

103. Ratier L, Urrutia M, Paris G, Zarebski L, Frasch AC, Goldbaum FA (2008) Relevance of the diversity among members of the Trypanosoma cruzi trans-sialidase family analyzed with camelids single-domain antibodies. PLoS One 3(10):e3524. doi:10.1371/ journal.pone.0003524

104. Deckers N, Saerens D, Kanobana K, Conrath K, Victor B, Wernery U, Vercruysse J, Muyldermans S, Dorny P (2009) Nanobodies, a promising tool for species-specific diagnosis of Taenia solium cysticercosis. Int J Parasitol 39(5):625-633. doi:10.1016/ j.ijpara.2008.10.012

105. Dolk E, van der Vaart M, Lutje Hulsik D, Vriend G, De Haard H, Spinelli S, Cambillau C, Frenken L, Verrips T (2005) Isolation of llama antibody fragments for prevention of dandruff by phage display in shampoo. Appl Environ Microbiol 71(1):442-450. doi:10.1128/AEM.71.1.442-450.2005

106. Greenberg AS, Avila D, Hughes M, Hughes A, McKinney EC, Flajnik MF (1995) A new antigen receptor gene family that undergoes rearrangement and extensive somatic diversification in sharks. Nature 374(6518):168-173. doi:10.1038/374168a0

107. Vincke C, Loris R, Saerens D, Martinez-Rodriguez S, Muyldermans S, Conrath K (2009) General strategy to humanize a camelid single-domain antibody and identification of a universal humanized nanobody scaffold. J Biol Chem 284(5):3273-3284. doi:10.1074/jbc.M806889200

108. Zou X, Smith JA, Nguyen VK, Ren L, Luyten K, Muyldermans S, Bruggemann M (2005) Expression of a dromedary heavy chain-only antibody and B cell development in the mouse. J Immunol 175(6):3769-3779

109. Janssens R, Dekker S, Hendriks RW, Panayotou G, van Remoortere A, San JK, Grosveld F, Drabek D (2006) Generation of heavy-chain-only antibodies in mice. Proc Natl Acad Sci USA 103(41):15130-15135. doi:10.1073/pnas.0601108103

110. Hofman EG, Ruonala MO, Bader AN, van den Heuvel D, Voortman J, Roovers R, Verkleij A, Gerritsen HC, van Bergen en Henegouwen PM (2008) EGF induces coalescence of different lipid rafts. J Cell Sci 121(Pt 15):2519-2528. doi:10.1242/ jcs.028753

111. Gainkam LO, Huang L, Caveliers V, Keyaerts M, Hernot S, Vaneycken I, Vanhove C, Revets H, De Baetselier P, Lahoutte T (2008) Comparison of the biodistribution and tumor targeting of two $99 \mathrm{mTc}$-labeled anti-EGFR nanobodies in mice, using pinhole SPECT/micro-CT. J Nucl Med 49(5):788-795. doi:10.2967/ jnumed.107.048538

112. Rahbarizadeh F, Rasaee MJ, Forouzandeh M, Allameh AA (2006) Over expression of anti-MUC1 single-domain antibody fragments in the yeast Pichia pastoris. Mol Immunol 43(5):426435. doi:10.1016/j.molimm.2005.03.003

113. Winichayakul S, Pernthaner A, Scott R, Vlaming R, Roberts N (2008) Head-to-tail fusions of camelid antibodies can be 
expressed in planta and bind in rumen fluid. Biotechnol Appl Biochem 53(Pt 2):111-122

114. Saerens D, Frederix F, Reekmans G, Conrath K, Jans K, Brys L, Huang L, Bosmans E, Maes G, Borghs G, Muyldermans S (2005) Engineering camel single-domain antibodies and immobilization chemistry for human prostate-specific antigen sensing. Anal Chem 77(23):7547-7555. doi:10.1021/ac051092j

115. Saerens D, Kinne J, Bosmans E, Wernery U, Muyldermans S, Conrath K (2004) Single domain antibodies derived from dromedary lymph node and peripheral blood lymphocytes sensing conformational variants of prostate-specific antigen. J Biol Chem 279(50):51965-51972. doi:10.1074/jbc.M409292200

116. Chan PH, Pardon E, Menzer L, De Genst E, Kumita JR, Christodoulou J, Saerens D, Brans A, Bouillenne F, Archer DB, Robinson CV, Muyldermans S, Matagne A, Redfield C, Wyns L, Dobson CM, Dumoulin M (2008) Engineering a camelid antibody fragment that binds to the active site of human lysozyme and inhibits its conversion into amyloid fibrils. Biochemistry 47(42):11041-11054. doi:10.1021/bi8005797

117. Chartier A, Raz V, Sterrenburg E, Verrips CT, van der Maarel SM, Simonelig M (2009) Prevention of oculopharyngeal muscular dystrophy by muscular expression of Llama single-chain intrabodies in vivo. Hum Mol Genet 18(10):1849-1859. doi:10.1093/hmg/ddp101

118. van Koningsbruggen S, De Haard H, de Kievit P, Dirks RW, van Remoortere A, Groot AJ, van Engelen BG, den Dunnen JT, Verrips CT, Frants RR, van der Maarel SM (2003) Llama-derived phage display antibodies in the dissection of the human disease oculopharyngeal muscular dystrophy. J Immunol Methods 279(1-2):149-161. doi:10.1016/S0022-1759(03)00232-1

119. Liu JL, Anderson GP, Goldman ER (2007) Isolation of anti-toxin single domain antibodies from a semi-synthetic spiny dogfish shark display library. BMC Biotechnol 7:78. doi:10.1186/14726750-7-78

120. van der Vaart JM, Pant N, Wolvers D, Bezemer S, Hermans PW, Bellamy K, Sarker SA, van der Logt CP, Svensson L, Verrips CT, Hammarstrom L, van Klinken BJ (2006) Reduction in morbidity of rotavirus induced diarrhoea in mice by yeast produced monovalent llama-derived antibody fragments. Vaccine 24(19):4130-4137. doi:10.1016/j.vaccine.2006.02.045

121. Harmsen MM, van Solt CB, Hoogendoorn A, van Zijderveld FG, Niewold TA, van der Meulen J (2005) Escherichia coli F4 fimbriae specific llama single-domain antibody fragments effectively inhibit bacterial adhesion in vitro but poorly protect against diarrhoea. Vet Microbiol 111(1-2):89-98. doi:10.1016/j.vetmic. 2005.09.005

122. Henderson KA, Streltsov V, Coley A, Dolezal O, Hudson PJ, Batchelor AH, Gupta A, Bai T, Murphy VJ, Anders RF, Foley M, Nuttall S (2007) Structure of an IgNAR-AMA1 complex: targeting a conserved hydrophobic cleft broadens malarial strain recognition. Structure 15(11):1452-1466. doi:10.1016/j.str.2007.09.011

123. DeLano W (2002) The PyMOL user's manual. DeLano Scientific, San Carlos, CA

124. Stanfield RL, Dooley H, Flajnik MF, Wilson IA (2004) Crystal structure of a shark single-domain antibody $\mathrm{V}$ region in complex with lysozyme. Science 305(5691):1770-1773. doi:10.1126/science. 1101148

125. Hadfield AT, Harvey DJ, Archer DB, MacKenzie DA, Jeenes DJ, Radford SE, Lowe G, Dobson CM, Johnson LN (1994) Crystal structure of the mutant D52S hen egg white lysozyme with an oligosaccharide product. J Mol Biol 243(5):856-872. doi:10.1006/ jmbi.1994.1688

126. Braden BC, Souchon H, Eisele JL, Bentley GA, Bhat TN, Navaza J, Poljak RJ (1994) Three-dimensional structures of the free and the antigen-complexed $\mathrm{Fab}$ from monoclonal anti-lysozyme antibody D44.1. J Mol Biol 243(4):767-781. doi:10.1016/00222836(94)90046-9

127. Bazl MR, Rasaee MJ, Foruzandeh M, Rahimpour A, Kiani J, Rahbarizadeh F, Alirezapour B, Mohammadi M (2007) Production of chimeric recombinant single domain antibody-green fluorescent fusion protein in Chinese hamster ovary cells. Hybridoma (Larchmt) 26(1):1-9. doi:10.1089/hyb.2006.037

128. Rothbauer U, Zolghadr K, Muyldermans S, Schepers A, Cardoso MC, Leonhardt H (2008) A versatile nanotrap for biochemical and functional studies with fluorescent fusion proteins. Mol Cell Proteomics 7(2):282-289. doi:10.1074/mcp.M700342-MCP200 